Research Report No. 56/2013

\title{
Private Law: Commutative or Distributive?
}

Dan Priel

Osgoode Hall Law School of York University, dpriel@osgoode.yorku.ca

Follow this and additional works at: http:/ / digitalcommons.osgoode.yorku.ca/clpe

\section{Recommended Citation}

Priel, Dan, "Private Law: Commutative or Distributive?" (2013). Comparative Research in Law \& Political Economy. Research Paper No. 56/2013.

http://digitalcommons.osgoode.yorku.ca/clpe/298 


\section{OSGOODE}

OSGOODE HALL LAW SCHOOL

YOR K UNIVERSITY

\section{OSGOODE HALL LAW SCHOOL}

Comparative Research in Law \& Political Economy

RESEARCH PAPER SERIES

Research Paper No. 56/2013

Private Law: Commutative or Distributive?

Dan Priel

Editors:

Peer Zumbansen (Osgoode Hall Law School, Toronto, Director Comparative Research in Law and Political Economy)

John W. Cioffi (University of California at Riverside)

Comparative Research in Law \& Political Economy 


\title{
Private Law: Commutative or Distributive?
}

\author{
Dan Priel
}

\begin{abstract}
Allan Beever, Forgotten Justice: The Forms of Justice in the History of Legal and Political Theory (Oxford: Oxford University Press, 20I3) xvi+325pp.
\end{abstract}

\begin{abstract}
Allan Beever argues in his new book that there are two distinct forms of justicecommutative and distributive-and that we have forgotten about commutative justice, the form of justice that governs our interpersonal relationships. Consequently, we erroneously think of private law from the perspective of distributive justice, the form of justice that governs our relation to the state. Forgetting commutative justice, he claims, has been a serious philosophical mistake with potentially grave practical implications. Theoretically, says Beever, the modern view is wrong, because politics and distributive justice are grounded in our pre-political, interpersonal relationships. In other words, commutative justice is logically prior to distributive justice. Practically, the dominance of the mistaken modern view has led us to think of people too much as part of a collective and not as individuals and to over-emphasize the significance of the state. In this essay I challenge all of Beever's claims. I argue that there is no basis for the claim that people these days have forgotten about interpersonal relationships, nor of the claim that interpersonal relationship are the foundation for politics. I challenge Beever's historical account, arguing both that Beever has failed to provide any convincing argument for why commutative justice has been forgotten, and that there are historical facts that explain the changes in the structure of private law that he ignored. I then turn to Beever's theoretical claims and argue that Beever's view about the independence of commutative and distributive justice are indefensible. Even accepting pre-political norms of commutative justice as the foundation of politics, it does not follow that contemporary contract law should reflect such norms. Finally, I argue that contrary to Beever's claim that commutative justice is apolitical, Beever's views reveal a clear political bent, which Beever never defends.
\end{abstract}

Note: A much shorter version of this essay will be published in Modern Law Review. In addition to what is mentioned in the abstract (which describes the shorter version), this SSRN version of the essay contains two additional sections. One is section VI, which examines whether Beever's view matches legal doctrine (and concludes that it does not), and a long Appendix, which argues that Beever's presentation of the various philosophers he discusses is often inaccurate and misleading. These sections are substantial, together making up more than half the text. Though not part of the review to be published, I believe they are important for a full assessment of Beever's book as well as for a more general evaluation of corrective justice views of private law. To be clear, it was only the shorter version that was the assessed and accepted by MLR, and the anonymous referee or editors of the journal have not passed judgment on these additional sections. MLR's acceptance of the shorter version in no way indicates that the journal accepted (or would have accepted) the additional sections.

* Associate Professor, Osgoode Hall Law School, York University. I thank Vincent Chiao, David Howarth, and Charlie Webb, and an anonymous referee for Modern Law Review for their comments. I also thank Michael Quinn for answering a few questions about Jeremy Bentham. 


\section{The Nostalgics}

Tort law, we are told, is under threat. There was a time when people understood its deep structure, its underlying logic, what it was about. These days are now gone. Nicholas McBride described the results of this change in near apocalyptic terms: 'the study of tort law has undergone a...catastrophe at some point in the twentieth century, with the result that we no longer really understand what we are talking about when we talk about tort law.' ${ }^{1}$ Less ominously, others have also harked back to older times when tort law was better understood and complained how ' $\mathrm{we}^{\text {', }}$ or at least 'they' (other academics, the courts), no longer understand the law. Ernest Weinrib wondered whether tort law 'ha[s] a future'.2 John Goldberg and Benjamin Zipursky waxed sentimental for that 'domain of law that was born centuries ago with the recognition of the writ of trespass vi et armis' and wondered '[h]ow is it that academics have lost their feel for this basic legal category ' $^{\prime 3}$ Robert Stevens admitted his views on tort law are 'conservative', ${ }^{4}$ and challenged many ideas that dominated twentieth century tort law thinking.

Allan Beever has been part of this chorus of nostalgics for quite some time. In a book published in 2007 he told his readers that the present problem with the law of negligence is that its 'unity...has been forgotten' and that we therefore have to 'rediscover' it. ${ }^{5}$ In his new book, he extends his argument in two ways: First, it is not just the unity of negligence law that's been forgotten, but that of the entire private law; and it is not just the law that has been forgotten, but the entire form of justice that underlies it. We have come to think of the world exclusively through lens of distributive justice, so that we no longer see that private law embodies a distinct form of justice, commutative justice. (Beever prefers 'commutative' to 'corrective' justice to highlight the fact that it is concerned not just with responses to wrongs, but with all interpersonal relations.) The source of all this is a philosophical confusion: the 'traditional' view he favours sees law (i.e. the natural law that exists pre-politically and

${ }^{1}$ N.J. McBride, 'Rights and the Basis of Tort Law', in D. Nolan \& A. Robertson (eds), Rights in Private Law (Oxford: Hart, 20I I) 33 I, 332. McBride models his story on A. MacIntyre, After Virtue: A Study in Moral Theory, 3rd ed. (Notre Dame: Notre Dame University Press, 2003). This is a rather odd choice for inspiration, as one of the ideas After Virtue is most famous for is that 'there are no such [things as natural or human] rights, and belief in them is one with belief in witches and in unicorns'. Ibid 69. McBride, by contrast believes that the source of the present 'catastrophe' is forgetting that tort law is a matter of rights and duties.

${ }^{2}$ See E.J. Weinrib, 'Does Tort Law Have a Future?' (2000) 34 Valparaiso U L Rev 56I.

${ }^{3}$ J.C.P. Goldberg \& B.C. Zipursky, 'Torts as Wrongs' (20I0) 88 Texas L Rev 9I7, 9I9.

4 R. Stevens, Torts and Rights (Oxford: Oxford University Press, 2007) 348. For the record, though unhappy about some developments in the 'I970s and I980s', ibid 349, Stevens seems more content with present-day English tort law. But like other nostalgics, he is critical of much of contemporary tort theory. See ibid 306-307.

${ }^{5}$ A. Beever, Rediscovering the Law of Negligence (Oxford: Hart, 2007) 5I2-5 I3, where Beever also mentions other aspects of the law that have been forgotten. 
that governs interpersonal relationship) as the foundation of political authority; the prevalent modern view reverses the relationship and sees all law as the product of politics (6).

This may seem like a rather abstruse debate but Beever thinks it has significant real-world ramifications: 'the modern conception leads us to misunderstand our law' (273), it made us forget 'what we ourselves know' to be true (242); it has even 'distorted our view of ourselves' (309). As an aid to failing memory, the book presents a historical account that seeks to chart the path that has led to our present unhappy state. Beever takes his readers on a tour through the works of some of the best known names in the history of Western philosophy with the aim of demonstrating how what 'we' once knew has become unknown. The story follows the familiar arc of rise and fall, with the traditional view getting its first articulation in ancient Athens, developing slowly until it reaches its apex in the work of Immanuel Kant. By then, however, the forces of decline have already begun to wreak havoc, and by the time we get to the present the modern view 'has become unconscious' (2); so unconscious that Beever does not expect the traditional view to 'make much sense to the reader, at least not until she has finished reading [the] book' (I). Nevertheless, it is an effort worth making, because the stakes could not be higher. The dominance of the modern view is not just of theoretical concern, it has had a terrible practical effect on our lives: it has led to us rely on the state to such a degree that we may soon be unwittingly descending towards totalitarianism (29I), caring too much about the community and not enough about individuals and 'overemphasiz[ing] the importance of the state' (309).

These are very bold claims, but as I hope to show Beever does not provide anything remotely sufficient to substantiating them. Sections II-IV provide some of evidence to challenge Beever's claims. Section V then shows the weakness of Beever's more theoretical claims. Section VI shows that, contrary to Beever's claims, legal practice does not reflect the traditional view, and section VII argues that contrary to Beever's claims that the traditional view provides a non-political foundation for private law, Beever's views have a clear political orientation.

\section{The Forgetting Thesis}

Beever's main thesis is that there are two distinct forms of justice-commutative and distributive-and that we have forgotten about commutative justice, the form of justice that governs our interpersonal relationships. Consequently, we see all law from the perspective of distributive justice, the form of justice that governs our relation to the state. As a result 'we do not understand the most basic features of our political or legal obligations to one another' (I). Furthermore, that perspective is 'by far the most fundamental' $(2)$ because it is only through these interpersonal relationship that states, politics, and distributive justice become possible. The heart of the problem is that contemporary writers on 'social, political, or legal philosophy' are 'all but exclusively 
concerned with the state' (I). What is missing is the perspective that involves people in relation to each other, regardless of the state. Much of the book then proceeds to contrast what Beever believes is the correct but forgotten 'traditional view' with the prevailing but deeply flawed 'modern view'. I will call this 'the forgetting thesis'.

Part of the difficulty in evaluating the forgetting thesis is that it is so fuzzily articulated. We are told that it is ' $\mathrm{we}^{\prime}$ who have forgotten about commutative justice, but it is never made clear who 'we' are. Sometimes it seems that it is all of us who have forgotten it, so that ' $[\mathrm{w}]$ hen we talk of public discourse, we talk almost as if we were creatures who relate to other individuals only via the state and its concerns' (309). At other times, it seems that while 'we' the people, actually still 'think in terms [of the traditional view] routinely' $(24 \mathrm{I})$, ' $\mathrm{we}^{\prime}$ the philosophers and academic lawyers have come to think in the wrong way (I4-29, 255-57, I73, 276). However, even this claim is qualified when Beever admits that the view has not been 'entirely forgotten' and then provides a long list (that could have been much longer) of prominent scholars who still follow the traditional view (8). At times Beever says that merely presenting his readers with 'the political world through the eyes of the traditional theorists...is no small task' because '[t]he modern view places a veil over all our thought that is very hard to lift' (6). Yet at other times Beever is confident that his readers will find ideas he associates with the modern view unintuitive (23I) and even 'too implausible to be taken seriously' (4 n.3). There are times when we are told that 'the fundamental structure of the private law remains based on commutative justice' (273), but elsewhere we are told that the single-minded pursuit of the impartiality of commutative justice 'is what the common law looked like' once, but that 'it does not look like that now' (306). In some places 'casual' reflection directs us immediately to the 'obvious' traditional analysis (252), while at other times, we are told that the 'language of the street', presumably the casual language of the layperson, 'is the language of the modern conception' $(246,252)$.

Even ignoring these ambiguities, can we say that anything like the forgetting thesis is true? The answer is unequivocally negative; in fact, as a historical matter quite the opposite is the case. Underlying Beever's thinking is a view that 'insists on treating individuals as such rather than merely as elements in the collective', ${ }^{6}$ and he sees the modern view, because it obliterates interpersonal relationships, as of a piece with this collectivist approach. As it happens, historical and anthropological research strongly suggest that this individualistic ethical stance is a relative historical novelty that appeared in the world of ideas at the same historical period Beever associates with the rise of the modern view. ${ }^{7}$ In historical terms, then, Beever gets things exactly backwards.

6 A. Beever, 'Our Most Fundamental Rights' in D. Nolan \& A. Robertson (eds), Rights and Private Law (Oxford: Hart, 2012) 63,87 note 82. Beever also says that a 'movement [that] propounds views inconsistent with interpersonal freedom... is not genuinely liberal at all' (292).

${ }^{7}$ See e.g. J. Haidt, The Righteous Mind: Why Good People Are Divided by Politics and Religion (New York: Vintage, 20I2) I6; L. Dumont, Essays on Individualism: Modern Ideology in 
When turning from history to contemporary reality, the view that individuals have certain obligations to each other regardless of politics or citizenship is utterly familiar. We live in a world saturated with social norms that no-one thinks of as related to the state: they range from relatively trivial matters like dress codes or the appropriate manner of addressing strangers, through matters that are on the borderline of morality like the appropriate way to behave towards one's neighbours or in a foreign country, to outright moral questions like the obligations we have towards the elderly, friends, the care for one's family and relatives and so on.

It would also be wrong to think that these views are acknowledged by most people but ignored by ivory tower academics. Moral realism is a controversial (although by no means unheard of) metaethical position, and it is standardly understood to be the view that one's basic moral obligations are universal and exist irrespective of the political unit one finds oneself in. Even without commitment to this view, virtually all the work in normative ethics is dedicated to exploring interpersonal obligations. It is for this reason that philosophers draw a distinction between moral and political philosophy, the former dealing with people's obligations to each other, the latter with the relationship to the state. As Beever cites titles of books on political philosophy as proof of our forgetting (I95), it is perhaps worth mentioning that what is probably the most widely discussed book in moral philosophy of the last two decades is entitled What We Owe to Each Other. ${ }^{8}$

Beever, of course, knows all this. He mentions the view that '[p]olitical and legal obligations emanate in some way from the state or society, but moral obligations are or can be independent thereof' (3). To overcome this obvious response to his claim, a response he considers 'wrong' (3), Beever gerrymanders the appropriate domain for his inquiry as the 'politico-legal' (II), a term that he invents. He then discovers, unsurprisingly, that he cannot find contemporary philosophy on interpersonal relationships. That does not show that people have forgotten their obligations to each other, only that Beever has excluded their views on such relations by definitional fiat. Even if we are ultimately convinced his classification of such relations as 'politicolegal' rather than 'moral' is superior, that does not show that such interpersonal norms have been forgotten.

I doubt, however, whether Beever's novel classification is superior. Beever suggests two ways of distinguishing politico-legal norms from 'mere moral' one. At one point he says that 'morality is focused on individuals as such' (3) rather than their relations with others. That is, to put it gently, a rather unusual definition of morality as it excludes virtually everything that most people talk about when they talk of morality. To get a

Anthropological Perspective (Chicago: University of Chicago Press, I986) 72-73 ('we have learnt to recognize by speaking of respectively traditional and modern views. For the ancients...man is a social being....For the moderns, under the influence of Christian and Stoic individualism, natural law, as opposed to positive law, does not involve social beings but individuals...').

${ }^{8}$ T.M. Scanlon, What We Owe to Each Other (Cambridge: Harvard University Press, I998). 
sense of how peculiar this definition is, it leads Beever to say that 'it would be odd to think that [the reason I should not hit my wife] was moral rather than political' (4), which I am confident is the exact opposite of how most people would think about the matter.

At a different point Beever offers a more functional distinction between the two kinds of norms, in that 'only [politico-legal] norms justify coercion' (3 I, also 20). This claim, as far as I can tell, is indirectly related to the claim that politico-legal norms are concerned with the right, while mere moral ones are concerned with 'the good' and with 'moral worth' (3I). This claim has the curious implication that Beever's politicolegal norms are, as a conceptual matter tied to the state, because as a conceptual matter they justify coercion. This is not true of the view of modern thinkers for whom the question of which norms are the business of the state is itself a normative question (with some thinking that promoting the good is the business of states, others rejecting this view). Even if we put the entire domain of 'mere morality' to one side, Beever's thesis still bears no relation to reality. Though he has some reservations about the term, Beever clearly aligns himself with natural law theory (e.g., 9-Io, I23-I25). If what has been forgotten is some version of natural law, then the forgotten thesis is false. A quick and unscientific search for English-language books with the term 'natural law' in their title published since the year 2000 returned dozens of such books. ${ }^{9}$ This is not to say that natural law theories have not changed through the ages or that there are no important differences among them. The point is that at the level of abstraction Beever addresses these issues, the ideas he talks about are a familiar part of the discourse.

The picture does not change when we consider Beever's more specific theses. Beever's main claim in political philosophy is that (natural law) norms of interpersonal relations are the basis for politics; his main thesis in legal theory is that these prepolitical norms form the foundations of private law. Beever presents the first thesis as something that most of his readers will find utterly baffling, indeed barely comprehensible. As we have all been looking at the world through 'the modern theorist's glasses', 'we have as yet no idea what the world would look like without them'. Once we took them off we would be able to see 'vistas few today imagine' (33). If by 'us' Beever refers to the general public, he may be right, because the questions he is interested in belong to a rarefied academic debate that most people do not bother themselves with one way or the other. But if we consider the target audience of this charge, that of political philosophers, the supposedly forgotten view that bases the justification of political institutions on interpersonal moral foundations is entirely

\footnotetext{
${ }^{9}$ I used www.worldcat.org, that conducts a meta-search of the catalogues of most academic and reference libraries in the world.
} 
familiar, and not just among those who see themselves as working within the natural law tradition. ${ }^{10}$

The same is true of Beever's claims regarding private law. Charles Fried's Contract as Promise, a book that argues that one can explain almost all of contract law in terms of promissory relations that exist between individuals outside the state, is not exactly an obscure book. In it, Fried rejects the view that justifies contract law for its ability to promote 'a distinct collective policy, the furtherance of economic exchange'. ${ }^{11}$ Fried argued instead that contract is based on the binding force of an exchange of promises, which he thinks is 'grounded not in arguments of utility but in respect for individual autonomy and in trust' ${ }^{12}$ Nor is Fried's the only attempt to explain contracts in terms of promises or other interpersonal relations. The same goes for tort law, where just in the last few years we have seen works with titles such as Torts and Rights and 'Torts as Wrongs' which espouse the supposedly forgotten view. Beever may have some disagreement over particulars with any of these scholars, but the key components of such views are exactly those he claims are now virtually forgotten. And while these views are by no means universally accepted, they are familiar and widely discussed. Similar views have also even been popular in criminal law. Despite the prominence of the state in present-day criminal justice system (as prosecutor, adjudicator, and enforcer), much of the resurgence of retributive theories of punishment has been attributed exactly to the view that sees criminal law as concerned with wrongs committed towards others (cf 87-88) and which sees criminal law's underlying theory as belonging to moral, not political, philosophy. Here too, the ideas in question are controversial, but the suggestion that they are somehow forgotten is absurd. ${ }^{13}$

Nor are such ideas merely the domain of academic debate. Some of the most discussed ideas in moral theory of our day have counterparts in social activism and political reform. Global justice, universal human rights, and concern for animals welfare (to name but a few) are all theoretical ideas with real-world counterparts, all largely based on the idea that people have obligations to others outside the state. Contrary to Beever's claims, one of the distinctive marks of the modern age is what Peter Singer called 'the expanding circle', the broadening of the domain of obligation

${ }^{10}$ For a discussion of this issue and a defence of the view Beever favours see L. Murphy, 'Institutions and the Demands of Justice' (I999) 27 Phil \& Pub Aff 25I. Besides himself Murphy identifies Joseph Raz, G.A. Cohen, Robert Nozick (and pretty much all libertarians) as proponents of this view. These are not exactly unknown figures in contemporary political philosophy.

${ }^{11}$ C. Fried, Contract as Promise (Cambridge: Harvard University Press, I98 I) 36.

${ }^{12}$ Ibid I 6.

${ }^{13}$ If I may be excused a personal note: a central theme of my tort law class, one that I repeat until my students are tired of hearing it, is that there are two ways of thinking of tort law. I call one of them the 'desert island view', according to the basis for understanding tort law should be (roughly) the same for people who find themselves stranded on a desert island (i.e., without any political community) as it is for us. I contrast this view with what I call 'the social welfare' approach. I do not hide the fact that I think the desert island view is wrong, but I do not hide it from my students. 
people think they owe to others (including non-humans) despite not having any relation (personal, familial, or national) to them. ${ }^{14}$ To an unprecedented degree, ours is the age in which people have concerned themselves, without any mediation by a state, with the lives of strangers.

\section{Mistaken History}

As mentioned at the outset, Beever seeks to bolster his claim about our present forgetting of commutative justice with a historical narrative. As the claim underlying the history is false, it is no surprise that the narrative aimed to show how we got here cannot support it. It would take more space than I have here to demonstrate just how inaccurately Beever presents the theorists he considers. Suffice it to say that whenever I checked the views Beever attributed to a philosopher against what that philosopher actually wrote, I found major discrepancies. ${ }^{15} \mathrm{I}$ limit myself here to the person Beever claims has made the single most significant contribution to the displacement of the traditional view, Thomas Hobbes.

According to Beever, the English Civil War 'had an enormous effect on [Hobbes's] thought...[which] helps us explain the form of Hobbes' theory' (I75) (never mind that Hobbes first expressed his ideas in The Elements of Law, which was written before the Civil War erupted). Beever explains that Hobbes became convinced that 'the ultimate cause of the English Civil War was the idea of a higher law' (179) (never mind that in Hobbes's book on the Civil War, which Beever does not mention, it is not the idea of a higher law' that troubled Hobbes, but that of divided authority to determine what the higher law means). ${ }^{16}$ According to Beever the effect of Hobbes's ideas was destructive. They 'blinded us to more accurate views of [the political and legal world]' and 'we have become so accustomed to our partial sight, that it is only with great effort and after much squinting that we are able to open our eyes' (195).

This claim is very difficult to square with Beever's own reading of Hobbes's work. Beever argues that Hobbes 'rejects the tradition without any justification at all' (202); not only that, despite his efforts to depart from the traditional view, 'Hobbes [was] committed to the existence of commutative justice and to the notion that it grounds all politico-legal obligation' (2OI-2O2). So according to Beever himself, Hobbes does not give any reason for departing from the traditional view, and then does not actually depart from it! If this is so, it is not clear why Hobbes should have been so 'influential' (202). The errors Beever attributes to Hobbes are not matters discovered only after close

14 See P. Singer, The Expanding Circle: Ethics, Evolution, and Moral Progress (Princeton: Princeton University Press, new ed., 20I I) especially I I I-I 24.

${ }^{15}$ See the Appendix to an online version of this essay, $n$ * above, where I provide many examples in support of this claim.

16 See T. Hobbes, Behemoth, or the Long Parliament /Chicago: University of Chicago Press, I990) dialogue I. 
analysis of Hobbes's arguments (something Beever never attempts to do); these are glaring blunders of a philosophical novice. Put slightly differently, if, as Beever suggests, Hobbes relied on the traditional view he supposedly repudiated, how did he 'ma[k]e people see the world in a different way' (I95)? Furthermore, even supposing we moderns cannot see those errors as our vision has become so clouded, Hobbes's contemporaries, at the time not yet exposed to the modern view, should have spotted them immediately. On Beever's retelling, rather than being an epoch-making figure, Hobbes should have been a minor figure in the history of thought, rarely read and remembered only by a few historians of political thought. ${ }^{17}$

Furthermore, Beever's story does not match the historical record. After his death Hobbes was often known as 'the Monster of Malmesbury', someone whose books contained dangerous heresies, not an influential figure whose ideas were embraced. It is therefore difficult to see the historical basis for Beever's claim that by the time Locke published his Two Treatises of Government the traditional view in England had already 'collapse[d]' (224) to such a degree that Locke could no longer even talk of commutative justice. Indeed, even today when Hobbes is widely read and often admired, he remains in many respects a notorious thinker. No matter how 'influential' he has been, Hobbes's readers have retained their critical faculties to such a degree that they have been able to reject what Hobbes must have considered his most important conclusion-the necessity of an unbounded political authority for the sake of social stability. Another problem with Beever's account is that even after Hobbes (and Bentham, and Rawls) 'we' have not stopped reading others. One of the most puzzling aspects of the forgetting thesis is that the thinkers Beever hails as the beacons of Truth are among the best known thinkers in history, philosophers whose place in the canon of Western philosophy could not be more secure. His list of traditionalists includes Aristotle, Aquinas, and Kant, who are still read, debated, analysed, taught, as well as criticized. No matter how 'influential' Hobbes has been, the suggestion that the ideas of Beever's traditionalists have been forgotten is indefensible.

\section{Missing History}

So far I have discussed what is in Beever's book, but it is worth spending some time on what is not; what, if you wish, Beever has forgotten. One of the striking features of Forgotten Justice is the limited extent to which the thinkers discussed in it are placed in their historical context. To the extent that they are, the only history Beever deems relevant is the history of kings and queens, of war and peace $(37-38,6 \mathrm{I}-62$, 90-9 I, 95-

17 The Appendix to the online version of this essay (see note ${ }^{\star}$ ) contains a longer discussion on Hobbes, which attempts to show why Beever is wrong to claim that Hobbes offers no reason for departing from the traditional view. 
98, I75-I78, 207-208). ${ }^{18}$ This leads to some rather odd historical claims, as when Beever tells us that Aquinas, Pufendorf, and Kant were all 'heavily influenced by the Holy Roman Empire' (96). ${ }^{19}$ What is utterly missing (rather surprisingly, in a book that aims to highlight the importance of interpersonal relationships beyond the state) is social, cultural, and technological history. So we read about the Glorious Revolution (208) but not a word about the industrial revolution, despite the latter's much greater impact on the shape of present-day private law; we read about the French revolution (203) but not about the scientific revolution, despite the fact that one cannot understand modernists like Hobbes or Bentham without taking into account the way they, explicitly and consciously, have sought to extend the methods of natural science to human affairs.

One gets only the briefest of hints from Beever's book of the fact that the modern states in the developed world are utterly different beasts from those that existed in the times of Locke, Kant, or even Mill (to say nothing of Aristotle or Cicero). Beever only acknowledges this at one point when he says that Aquinas, Pufendorf, and even Kant lived at a time in which 'the centrality of the state...would have seemed highly questionable, if not strange' (98), but he does not draw from this the conclusion, that at least as a descriptive matter it is the modern view that corresponds to present-day political reality. Consequently, it is not 'modern theorists [who] have adopted an understanding of the political and the legal that is fundamentally wrong' ( $\mathrm{I}$ ), but traditionalists like him who claim we would get a better grasp of the politico-legal reality of our time by reading works written by people living in, and writing against the background of, an entirely different political environment.

Because Beever is not alone among contemporary traditionalists in ignoring this broader historical context, it is worth relaying it in slightly greater detail. In the supposed glory days of respect for interpersonal relationships, when the state and distributive justice were (at best) only a remote presence in most people's lives, what one finds is not so much respect for interpersonal relationships, but levels of interpersonal violence dramatically higher than those found in developed countries today. To this day, non-state societies have average homicide rates that are orders of magnitude higher than those found in state societies; and the same is true of Western societies in the pre-modern age. For instance, the homicide rate in fourteenth century Oxford was more than a hundred times higher than the homicide rate in contemporary London. ${ }^{20}$ In today's western countries, where the state is most prominent, women-

${ }_{18}$ That in itself is another sense in which Beever's book ignores history, for one of the most dramatic developments in historiography to have taken place in the course of the last century has been the expansion of what counts as 'proper' history far beyond political history. See R.J. Evans, In Defence of History (London: Granta Books, new ed., 2000) I6I-I63.

${ }^{19}$ Incidentally, Kant lived his entire life in Königsberg, which at no point during his lifetime was part of the Holy Roman Empire.

${ }^{20}$ See the statistics collected and discussed in S. Pinker, The Better Angels of Our Nature: Why Violence Has Declined (New York: Viking, 20I I) chs 2-3. The data on declining homicide rates come 
more than half the world's population-enjoy more 'interpersonal independence' (292) than they have had at any point in recorded history. ${ }^{21}$ Many attribute these dramatic changes, at least in part, to the rise of the modern state. ${ }^{22}$ Though it is difficult to be certain about causality on such matters, at the very least the data suggest that individuals' concern for interpersonal relations alone may not be powerful enough to guarantee people's safety from others. They also undermine the suggestion that because of an ever-present Leviathan we have collectively forgotten about interpersonal relations.

It is also worth reminding that though the state is in some respects a more prominent feature in our lives these days, it is much less so in others. Jeremy Bentham, a modernist according to Beever, was among the first to call for decriminalizing sexual 'irregularities' in the name 'all comprehensive freedom'. Immanuel Kant, probably Beever's foremost traditionalist, believed that it is the state's business to punish these violations of natural law. ${ }^{23}$ Here is what Bentham had to say of the idea of criminalizing certain sexual practices: 'If there is one idea more ridiculous than another, it is that of a legislator who, when a man and a woman are agreed about a business of this sort, thrusts himself in between them, examining situations, regulating times and prescribing modes and postures' ${ }^{24}$ Beever's account makes it hard to understand why such words sound so obvious to modern ears.

The history of scientific and technological development is also forgotten in the works of the nostalgics. Beever manages to write a book tracking the historical development of contemporary ideas on private law without mentioning the fact that these days (but not in the days of Locke or Kant) most adults in many parts of the world are in charge of machines that can cause death or serious injury to others, not because of forgetfulness of the importance of interpersonal relationship, but due to a moment's carelessness. Those who lament the supposedly skewed contemporary vision of tort law as 'accident-law-plus', ${ }^{25}$ forget that it reflects modern-day reality:

from T.R. Gurr, 'Historical Trends in Violent Crime: A Critical Review of the Evidence' (I98I) 3 Crime et Iustice 295. As Beever is so concerned about collective forgetting of interpersonal relationships, it is worth quoting from this essay: 'early estimates of homicide rates and their contemporary descriptions all sketch a portrait of a society in which men (but rarely women) were easily provoked to violent anger and were unrestrained in the brutality with which they attacked their opponents. Interpersonal violence was a recurring fact of rural and urban life'. Ibid 307.

${ }^{21}$ See the discussion on the decline in violence against women in Pinker, above n 20, 394-4I5.

22 See ibid I2I, 68I. The thesis is associated with N. Elias, The Civilizing Process (Oxford: Blackwell, rev. ed., 2000), who suggests a causal link between the two at 367-376.

${ }^{23}$ On Bentham's views see L.C. Boralevi, Bentham and the Oppressed (Berlin: de Gruyter, I984) ch 3; on Kant's see J. Finnis, 'Legal Enforcement of Duties to Oneself: Kant vs. Neo-Kantians' (I987) 87 Colum L Rev 433, 446-452.

${ }^{24}$ J. Bentham, 'Essay on "Paederasty"' (part 2) (I978) 4 Journal of Homosexuality 9I, IOO-IOI. (This is a transcription of an unpublished manuscript written around I785.)

${ }^{25}$ Golberg \& Zipursky, n 3 above, 9 I7. 
much less interpersonal violence than in the olden days of assault and battery, but many more accidents.

Even limiting ourselves to the world of ideas, Beever forgets that we live in the world of risk and probability, theoretical concepts largely unknown before the eighteenth century, but now so prevalent we no longer notice their ubiquity. The development of notions of risk is not just the product of mathematical advances, but also due to wealth of statistical data that makes risk assessments possible. (The word 'statistics' bears witness to this science's historical connection to the rise of the state). The methodical collection of such data, though it had some predecessors, began in earnest only in the nineteenth century. ${ }^{26}$ Consequently, in its modern sense 'risk', contrary to Cardozo's famous words in Palsgraf v Long Island Railroad, is not 'a term of relation ${ }^{27}$ but one of pooling different people (and events) together.

As none of this makes it to Beever's story, we are left puzzled when we read that the traditional view declined 'after the convulsion set off by Hobbes and the English Civil War' (6), especially as Beever himself says that this 'decline was not the result of a confrontation between the traditional and the modern view won by the latter', but rather the result of a "paradigm shift" in the way that people thought about politics' (6). Thomas Kuhn, who coined the term, argued that paradigm shifts occur when there is an accumulation of empirical findings that cannot be explained within an existing scientific paradigm. ${ }^{28}$ Obviously, by using Kuhn's term, Beever is not obliged to accept Kuhn's analysis of it, but as he denies anything like this was the cause of the paradigm shift in this case, he needs to supply an alternative explanation. This is no small matter. The forgetting thesis is the central thesis of Beever's book, and if it were true, it would count as one of the most dramatic transformations in human (intellectual) history. How did we come to forget our interpersonal relationships? The two culprits Beever mentions just won't do: on Beever's account blaming Hobbes, as we have seen, makes no sense; as for the Civil War, apart from its supposed influence on Hobbes, it is unclear what, if anything, it had to do with the decline of the traditional view.

As the forgetting thesis is false, we need not trouble ourselves too much with this question. The broader historical canvas, however, suggests an alternative story that provides part of the explanation of the state of contemporary private law. This story is not about forgetting of interpersonal relations, but of remembering the world we live in

${ }^{26}$ See I. Hacking, The Taming of Chance (Cambridge: Cambridge University Press, I990) chs I2; T.M. Porter, The Rise of Statistical Thinking I 820-I900 (Princeton: Princeton University Press, I986) chs I-3. On the slow reception of notions of probability and risk into commerce and insurance see L. Daston, Classical Probability in the Enlightenment (Princeton: Princeton University Press, I988) I38-82.

27 (I928) I62 N.E. 99, IOI. What exactly is the interpersonal relation in the heightened health risks from insufficient sleep? The only relation is that the studies that discovered this did this on the basis of the study of a large group of people who are otherwise completely unrelated.

${ }^{28}$ See T.S. Kuhn, The Structure of Scientific Revolutions (Chicago: University of Chicago Press, 4th ed., 2OI2) chs 6-8. 
and adapting the law to an environment radically different from what it had been three centuries ago. It is true that private law changed by taking broader social considerations into account, but this happened not because people have forgotten about interpersonal relationships. It is because, rightly or wrongly, those in charge of the development of private law have come to see (sometimes only semi-consciously) that private law would function less well than other alternatives in the circumstances of the modern world, if it maintained its 'traditional' form. In part, change was necessary because the environment and society that the law had to deal with were very different than before; in part, it was needed because lawmakers had more information and better institutional tools available to them that could be harnessed for improving the law. And as the pace of these developments-social, political, scientific, technological, demographic-has dramatically accelerated in recent times, it should not be surprising that ideas or doctrines that may have served people reasonably well from Aristotle to Locke, became obsolete (or at least in need of updating) within a fairly short time.

\section{Beever's Theoretical Claims}

I have spent considerable space on Beever's historical thesis, because it is the central idea animating his book and it takes up more than two-thirds of it. Those sympathetic to Beever's position could still maintain that one can reject his forgetting thesis and ignore his historical narrative and still believe that private law is better understood in terms of commutative justice than in terms of distributive justice. This is unquestionably true. It is therefore necessary to examine the traditional view on its own terms. In this section I will largely ignore Beever's historical narrative and examine Beever's claims regarding the problems with the modern understanding private law. I will argue that Beever does not provide any good reason to favour of the traditional view and that he fundamentally misunderstands the modern view. ${ }^{29} \mathrm{I}$ have divided the discussion into three somewhat overlapping topics: the supposed conceptual claim about the nature of private law; the role of private law institutions; and Beever's neglect of the implications of his own traditional view.

\section{The Conceptual Claim}

Behind Beever's historical narrative, lies what he considers is a conceptual point (308): Beever seeks to convince his readers that there are two distinct forms of justice, each with its own domain and neither reducible to the other. He seems to think that by pointing out that a form of justice 'exists' and that it matches a certain practice, he has done enough to show that that practice is better understood in terms of that form of

${ }^{29}$ For a different discussion of the problems with a corrective justice view of private law, both in general and with special focus on the law of unjust enrichment, see D. Priel, 'The Justice in Unjust Enrichment' (unpublished). 
justice, and that it would be wrong to conceive of it differently. For example, he says, '[Aristotle's] claim is...that corrective justice ought to be done because corrective justice demands it. That is what it means for corrective justice to be a form of justice' (73). The context leaves no doubt that Beever shares this view.

This passage raises an intriguing question that Beever never carefully addresses, which touches on the relationship between commutative and distributive justice. This may seem like a borderline question that need not affect the 'internal' analysis of the 'nature' of commutative justice, but as I hope to show it is central to the evaluation of Beever's position. One possible way of understanding the relationship between commutative and distributive justice is that they occupy (to borrow a phrase from Stephen Jay Gould) two 'non-overlapping magisteria'. We can classify events in the world as belonging exclusively to commutative justice or to distributive justice (and probably some that fit neither), but no event raises questions for both. It follows from this view that there can be no conflicts between commutative and distributive justice. (There is, I think, some reason to think that this is how Aristotle understood the relationship between the two, but I will say nothing here to substantiate this claim.)

In some instances it looks as though Beever believes that this is the correct view. For example, it fits his view that limits distributive justice to redistribution (279). In a different (and perhaps inconsistent) formulation he says that an act constitutes 'distributive injustice only if the reason it is wrongful is that it results in an unfair distribution of benefits and burdens amongst the community' (107-I08, also I37, cf I45). On this view, it seems, distributive justice is not about the redistribution of resources. On this view distributive justice is about what individuals should be asked to contribute (burdens) for the sake of certain public goods (benefits). That is an inegalitarian conception of distributive justice, which needs to be backed by a normative argument, not presented as a conceptual truth. ${ }^{30}$

Even if this view is correct, it still has to address the fundamental problem of explaining property (and by implication property law) exclusively in terms of commutative justice. Beever himself thinks of property as 'relationship to things' (205) which bind the whole world (as opposed to the rights against other people in the rest of private law). Beever's defence of this view amounts to the claim that the rules [of property law] do not refer to issues of distributive justice and...they are oblivious to distributive outcomes' (I46). Even if true (and that is, in fact, a very contentious claim), this response does not address the problem, which is that because property rights impose limits on all others, they cannot be grounded only in interpersonal relations, because no human has interpersonal relations with all other humans. The charge is that for this reason property requires political institutions that create rights that bind everyone (whether or not the resulting property regime is 'oblivious to distributive

${ }^{30}$ This view is perfectly in line with Beever's political stance as it emerges from the book. See the discussion in section VII below. 
outcomes'). As Beever acknowledges, something like this view can be found even in the works of traditionalists Pufendorf and Kant (I37, I6I).

A second problem, seemingly more technical but no less significant, is that Beever does not hint at what happens to property upon the death of its owner, at least when she died intestate. Do rules of inheritance belong to commutative or distributive justice? As death does not (necessarily) involve a bilateral relationship, it is hard to see how commutative justice could be relevant, and it is not part of Beever's own statement on the scope of commutative justice (205). If so, then Beever is wrong to say that commutative justice alone suffices for governing property. Even if inheritance is somehow included in commutative justice, what does it say about it? Does private property return to the commons upon death (in which case positive law does not merely enforce commutative justice but changes it), or does it automatically become the private property of other people? ${ }^{31}$ Does it call for primogeniture? ${ }^{32}$ Can commutative justice tell us how much should the spouse get in relation to the children? Should males and females have equal shares? (A negative answer to this question seemed as obvious to many of Beever's traditionalists as an affirmative one was obvious to moderns like Bentham or Mill, to say nothing of those who came after them.) Is the property held jointly by all successors, or does each get an exclusive ownership in a share? If it is the latter, what is the standard for division: equal shares per person, or some other measure (e.g., the amount of love and affection each relevant person had bestowed on the deceased)? Who are the relevant persons for shares: is it limited to one's family, or do loving friends get a stake as well, perhaps even prior to ungenerous children? As death, alas, has happened a few billions times in the course of human history, these questions can hardly be brushed aside as quibbles over trifles.

All this does not bode well for Beever's overall point, which is that private law 'is not about "the way of life of the peoples"' (205, quoting and rejecting Montesquieu). The different answers that can be (and have been) given to the questions posed above about inheritance are examples of the role of social values in private law. Even within the core of private law that Beever talks about, how are to think of the old rule that women (largely) lost their capacity to enter into contracts upon getting married? How are we to think of changes in the way property law has treated marital property during

${ }^{31}$ Blackstone (and probably Kant as well) believed natural law sanctioned the former, Locke the latter. (Neither spoke of commutative justice in this context.) See W. Blackstone, Commentaries on the Laws of England (Oxford: Clarendon Press, I765) ii, I3 ('the law of nature suggests, that on the death of the possessor, the estate should again become common...unless otherwise ordered for the sake of civil peace by the positive law of society'); J. Locke, Two Treatises of Government, P. Laslett ed (Cambridge: Cambridge University Press, I988) 206-207, 2 I0 (§§I.88-89, I.93) ('nature appoints the descendent of [parents'] Property to their Children, who thus come to have a Title, and natural Right of Inheritance to their Fathers Goods', quote from §I.89).

${ }^{32}$ Calvin spoke of the 'natural rights of primogeniture'. See J. Witte, Jr., The Reformation of Rights: Law, Religion, and Human Rights in Early Modern Calvinism (Cambridge: Cambridge University Press, 2007) 58. Locke explicitly rejected this view. See Locke, n 3 I above, 2 Io (§I.93). 
their relationship and upon its dissolution, of what belongs to the 'things' that according to Beever property law is about (205), or of harms are recognized by tort law? On Beever's view the only way to explain such changes is as the correction of some conceptual error about the nature of private law. I think a more natural way to think them of them is as reflecting 'the way of life of the people'. How are we to decide between these competing explanations? If changes in private law had been the result of 'conceptual' errors and had nothing to do with prevailing social views, we would have expected to see no correlation between changes in private law and changes in social attitudes. But of course that is precisely what we do not find. In all the examples I gave (and in many others I did not) changes in private law and in social attitudes have been in tune.

For such reasons the non-overlapping magisteria view looks like a dead-end, and at times Beever himself seems to have a different understanding of the relationship between commutative and distributive justice. He acknowledges that commutative justice may have political (305) and distributive (I66-167) consequences. Now, if this is the case and if (as Beever thinks) commutative and distributive justice are distinct forms of justice irreducible to the other, then necessarily there will be conflicts between them, i.e. cases in which following commutative justice will have effects that make matters distributively worse. Beever's view amounts to the claim that in all such conflicts, we should follow commutative justice, but since there is nothing in Beever's book that directly addresses this question, he offers no reason to think that in any (let alone every) case of conflict, we should prefer commutative to distributive justice.

Here is another way of making this point: a lawmaking body can fully accept Beever's way of dividing commutative and distributive justice and simply treat the kind of events we classify under 'private law' exclusively on the basis of distributive justice standards. It is plainly not impossible to do so-New Zealand's accident scheme is an example of doing just that. But if ignoring commutative justice altogether is conceptually possible, then clearly taking it into account alongside other considerations is conceptually possible as well. This may be undesirable, but there is no conceptual difficulty with doing so. If Beever is troubled that the resulting legal regime is not 'genuine' tort law, so be it: we'll call it schmort law; and if such a position is not 'genuinely liberal' (292), so be it: it can be genuinely schliberal. What matters is if it's overall better, not whether it fits a label.

The picture gets even more complex once it is acknowledged that virtually all modern states routinely use what in Beever's terms are commutative justice events for the sake of promoting distributive goals: in many states, most sales (commutative justice events) are an occasion for the collection of tax (a distributive justice event); the same is true of income for labour, which Beever treats as a clear example of commutative justice (279). If such taxation is unobjectionable (and Beever says nothing to the contrary), there is no principled reason why a negligence case (a commutative justice event) should not also be an occasion for distributive justice. There may be normative considerations against doing so, but there is nothing that conceptual 
analysis of private law or of commutative justice that bears on the question whether courts should do so. For even if we accept such conceptual arguments, all they amount to is that such considerations do not 'belong' in tort law (which 'genuinely' is exclusively about commutative justice). In response we could just say that tort law events require courts to take into account commutative justice considerations (as found in tort law, strictly so-called) alongside with distributive ones.

\section{The Institutional Argument}

All this shows the pointlessness of trying to win normative debates by appeal to conceptual analysis. Sensing perhaps the weakness of these conceptual arguments, Beever bolsters his normative conclusions with arguments relying on the institutional limits of courts and their lack of legitimacy to decide political questions. So understood, there is nothing in any event that forecloses taking distributive considerations into account, but there are constraints on the body that decide such cases, that limit the sort of considerations it should rely on.

Unlike the conceptual arguments, these are valid concerns, but they need to be considered carefully. One reason to doubt such arguments is that they prove too much. If such arguments were convincing, they would require a significant change in the way courts have operated for several decades now in the domain of public law. Even if Beever is interested in private law, it is surprising, to say the least, that he does not acknowledge the full scope of his arguments and the extent to which they would require not just some rethinking in private law, but also rolling back decades of public law developments as well. Simply as a matter of sheer numbers, if it is institutional capacity and political legitimacy he is concerned about, the role courts often play in constitutional litigation should have worried him much more. ${ }^{33}$

Beever might reply that he is happy (or sad) to report that in his view much of public law adjudication is politically illegitimate but that unlike the lost cause that is public law, in private law there may still be hope in returning the law to its proper, traditional, origins. But even within the domain of private law, it is unclear whether courts could satisfy his strictures. Beever's argument, a familiar point in the work of tort law nostalgics, is that when the court decides an issue according to commutative justice 'it is able to determine how the gap should be filled by considering justice as between the parties', hence 'its law-making need not be political' (302). Notice first how Beever changes his analysis to fit his desired conclusion: earlier in the book Beever designated private law and commutative justice to what he called the 'politico-legal'

${ }^{33}$ One more sense in which the nostalgics' work yearns for bygone days is the extent to which it studiously ignores public law. Cf D. Priel, 'The Political Origins of English Private Law' (20I3) 40 JL \& Soc 48I, 50I. Beever provides an excellent example: 'We do not go to court for [achieving distributive justice]. We go to court to have our rights vindicated' (306). This not only ignores most law, that these days does not originate in the courts (itself to a great extent a twentieth century development), but even much of the law that does. For a seminal discussion see A. Chayes, 'The Role of the Judge in Public Law Litigation' (I976) 89 Harv L Rev I28 I. 
domain. By the end of the book, in addressing a different question, the boundaries are redrawn so that private law is no longer political. In any case, even if private law is by some measure completely non-political, Beever's conclusion does not follow. The institutional concerns about judges deciding political matters is not due to the fact that there is some category of 'political' questions that judges are inherently forbidden to consider; the concern is with having them decide questions with certain characteristics that make them (according to this line of reasoning) inappropriate for judges to decide. If decisions in other domains have similar characteristics, they are equally problematic, even if they are not 'political'. (In truth, since there is no preordained list of 'political' matters, we are likely to consider a matter 'political' if it has these characteristics.) Questions raise similar concerns for institutional capacity and legitimacy when the following three conditions obtain: the question relates to matters affecting the life of large numbers of members of a community; the answers are controversial among members of the public; and there are no deemed experts capable of deciding them 'correctly'. Whether or not classified as 'political', questions about the scope of tort liability often meet these criteria.

Beever concedes that there may be disagreements on questions of private law (302) but denies that this fact undermines judges' capacity to decide them (304). But why should such matters be handed to judges even if they may be publicly controversial? Beever's answer is that 'judges have superior expertise with respect to commutative justice' (306). In other words, he thinks that the last of the three characteristics identified above for institutionally problematic decisions does not obtain. But judges' expertise on commutative justice is an empirical claim for which he gives no evidence, and it is unclear what would make them such experts. It is not as if there is some sort of certification or specialization that can show one to be an expert on commutative justice in the way one can be shown to be an expert on the rules of contract law, and to argue that judges' expertise in contract law makes them experts in commutative justice is precisely what Beever needs to show. It cannot simply be the fact that because judges are required to think about commutative justice they have developed expertise on the subject, for if that were the case, we could just expose judges to the broader range of issues required to make good decisions on distributive justice and thus make them experts on political questions. In fact, if constant exposure to a question is sufficient for such expertise, arguably contemporary judges could claim expertise in distributive justice since public law litigation constantly exposes them to it. Even if this can be shown that judges are experts on commutative justice because legal doctrine embodies it, that would just beg the question why doctrine should match commutative justice (and not something else). Since it is possible to decide such questions on other grounds, if most members of a community prefer a different legal rule which they justify on (say) distributive justice grounds, why should they not get to enact it? Finally, if Beever's forgetting thesis is correct, we should be sceptical of the alleged judicial expertise on questions of commutative justice. After all, it is the judges who have been encumbered by politics in the domain of public law and who have often 
blurred the boundaries between the two; it is the judges who read those academic articles peddling the modern ideas. The people, by contrast, are according to Beever himself, less exposed to such dangerous nonsense, and so (either directly or through their elected representatives), should be given to decide these matters.

This shows that even if we accept Beever's argument wholesale, all that follows is that judges should decide cases on commutative justice grounds if we wish to have such cases decided on non-political grounds. Society could prefer to have such cases decided politically and designate it to a non-judicial body that would be empowered to decide such cases on distributive grounds. Beever does not directly address this question but some remarks he makes reveal his attitude to such suggestions. One option is to turn these matters to the legislature which (if functioning properly) avoids both the problem of legitimacy and the problem of lack of institutional capacity. Nevertheless, Beever believes that when the legislature intervenes in the domain of private law, its role should be limited to 'remov[ing] obstacles to the achievement of commutative justice' (306). This view does not follow from anything Beever has argued for. One may accept that there are some pre-political natural law norms, one may even grant that some such norms are necessary for establishing a political community so that in some sense some law is prior to politics. It does not follow that after the polity's establishment, it should simply try to enforce these pre-political norms to govern the interpersonal relationships that exist within a political community. The legislature may choose to do that, but it may equally decide to replace them with others. To deny this is tantamount to the claim that there are substantive limits on the law-making powers not just of courts, but also of legislatures, which go beyond anything that may be written in any constitution. (This implies that according to Beever himself, courts and legislatures lack political authority in this field: 2 I 5, cf I78.) But nothing, either in the conceptual 'nature' of private law, or in the traditional view's priority of law to politics warrants this conclusion. Once we abandon the nonoverlapping magisteria view, distributive justice considerations do not miraculously lose their validity in the context of a commutative justice event, and a legislature may enact laws that reflect that.

Beever strongly disapproves of such ideas. He considers the possibility of appointing to an 'social policy expert[s]' (300) to an administrative body that would decide such cases on the basis of distributive justice, but finds such a solution would be 'repellent' and 'unjust' (300). But what if these policy experts were to give their recommendations that would then be enacted by the legislature, leaving judges with politically unproblematic task of applying these rules, where is the problem? I speculate that he considers such a solution 'unjust' because it would not comply with the principles of commutative justice. But, to the extent that commutative and distributive justice may conflict, entrusting courts to decide such cases on the basis of commutative justice would also be unjust, distributively unjust. In such a case, the only question is whether society prefers commutative injustice to distributive injustice 
or vice versa, but on this view, either way there will be an injustice. Without further argument there is no reason to prefer one sort of injustice over another.

And why is such a suggestion 'repellent'? Courts are on Beever's view a kind of administrative body staffed by commutative justice experts, so what is the problem with appointing experts on distributive justice and enacting their recommendations (leaving decisions to judges based on legislative rules promoting distributive justice), or even turning the entire matter for distributive experts to decide? I believe Beever's visceral reaction to such a solution tells us something about his views on distributive justice, namely that he doubts there is any expertise in the domain of distributive justice, that at least in the sense used in contemporary political theory, it is just a fancy name for a free-for-all fight for a larger share of society's resources. Administrators placed to decide such matters would be 'repellent' because they would inevitably impose their own preferences and prejudices. As a result, this solution would be a form of tyranny with the power to take property from some and give it to others. By contrast, I suspect Beever believes commutative justice is a product of Reason, a domain on which one can have a rational debate. I cannot be sure that this is Beever's view, but much of what he says fits it, as does what he does not say: there is no real discussion in the book of what Beever thinks the proper domain of distributive justice is, and more importantly, there is no attempt to articulate, even in general outline, some way of resolving conflicts between distributive and commutative justice.

The practical effect of Beever's view is that certain events will be decided on the basis of commutative justice alone. Beever seems to think that this follows from the fact that courts are institutionally-constrained, but in fact, in such cases we face a choice: If we are convinced that certain events raise both commutative and distributive justice considerations (which seems to be Beever's view) and that judges are institutionally incapable of deciding such matters taking into account all the relevant considerations, then the institutional question is this: should we leave the decision to a body that is not going to take all relevant considerations into account (thus guaranteeing its decisions may well be all-things-considered wrong), or are we removing the decision from that body and giving it to a different one that can take all considerations into account. There is no obvious answer to this question, for the benefits from awarding the decision to bodies that decide on narrower grounds (simplicity, fewer controversies) may outweigh the benefits from deciding based on all the relevant considerations. But such a question, if taken seriously, requires careful consideration. The view that it would always be better to give decision-making power on such matters to the more institutionally-constrained body without any argument seems motivated by different concerns, political ones. As I will argue below, Beever's book reveals his political preferences, and the priority he gives to commutative justice in cases of conflict matches those preferences. 


\section{The Missing Alternative}

So far this section ignored history, but it is worth returning to the broader historical picture presented earlier for an alternative understanding of commutative justice. On this alternative view commutative justice is not a distinct form of justice but a distinct form of regulation. Its two most important distinguishing characteristics are after-thefact response to claims brought about by individuals. (This is easiest to understand with regard to tort law, but it is true of other branches of private law as well.) These features are the main reason why this form of regulation was until fairly recently (by and large) the only form of regulation available, why, in other words, it seems to correspond to a 'traditional' view of the law: it is typically the simplest form of regulation. Once technology opened up new possibilities, it became possible to think of news ways of regulating many of events previously regulated by commutative justice.

I offer the characterization of commutative justice as a form of regulation as a competing understanding to Beever's. The question now is which of these two interpretive possibilities better explains and illuminates our practices. Though plainly this is not a matter that can be explored here in any detail, I believe the historical evidence briefly sketched earlier supports the view that sees what is known as 'commutative justice' as a form of regulation. Many puzzles about commutative justice and its relationship with distributive justice are resolved once we understand it in this way.

Beever's ignoring this possibility may explain why he says nothing about another regulatory possibility, one that he should have found particularly attractive, a more 'genuinely' private version of private law than the one he discusses. People can make agreements and rely exclusively on their sense of the binding force of promises (or whatever) as the reason to abide by them; people can accept a pre-political obligation to repair harms (or wrongs) they cause others by making amends in the form of monetary compensation, public apologies, or any other form. So long as the state does not interfere with such actions, this form of 'private law' would be a much better example of commutative justice (in its purely interpersonal, bilateral sense) than the one governed by state institutions. (Admittedly, part of the reason why people may fulfil their contractual obligations or agree to pay compensation in such cases may be their concern for their reputation in the eyes of third parties. Still, the state would not be involved.) If Beever is concerned for the preservation of interpersonal relations, he should have argued for this, at least as an ideal to aspire to. After all, even if state courts strictly limit themselves to commutative justice and to enforcing people's prepolitical rights, in playing an active role in enforcing such rights, they may plant in people's minds what Beever considers the bane of our modern existence, the tendency to 'overemphasize the importance of the state and overestimate its ability to facilitate justice' (309). In other words, if Beever really is troubled by the state and the dangerous role it has come to play in our lives, if he really is concerned for our interpersonal freedoms being crushed by the state, it is odd that he never considers the removal of 
the state from private law. This is no mere libertarian utopianism: There are some writers who have written admiringly on examples of this more private form of regulation. ${ }^{34}$

To those less troubled by the presence of the state in their lives such studies, though valuable, highlight (perhaps inadvertently) the limits of this form of regulation: First, they typically work only among fairly close-knit or small groups where informal mechanisms for enforcing compliance can function well. Whenever these conditions are not found, one inevitably finds complex institutional mechanisms that supplement (rather than merely enforce) pre-political private law. ${ }^{35}$ Online markets function as well as they do because of sophisticated trading platforms (provided by a third party that sets up the rules and as such fulfils a similar role to the state) that can facilitate the trust that would otherwise be difficult to maintain among strangers. Second, such forms of 'opting out' piggy-back on the state. The historical evidence mentioned earlier, as well as contemporary data on countries with weak political institutions, strongly suggest that peaceful mechanisms that allow neighbours to settle their disputes without law, are easier to sustain when a state with well-functioning institutions exists in the background.

Recognition of the conceptual possibility of a form of regulation more private than the one Beever discusses also makes it easier to understand why when the state is involved there is no basis for limiting a priori the kind of considerations it can bring to bear in adjudication. Those who manage their affairs on their own can decide on whatever rules fit their fancy; when the state is involved by providing a set of enforceable rules (i.e., when the state mobilizes its power to guarantee others' compliance), it provides a service needed exactly by those who worry that the truly private form of private law would not suffice. Two points follow: first, there is nothing odd about the idea that on this view 'contract law is seen as an imposition on freedom rather than the realization thereof' $(270)$, for that is precisely what contract law is for: it is an institution that brings in a third party-the state-to compel (or guarantee or signal) compliance. ${ }^{36}$ As such, contract law can be seen as an imposition on freedom for the sake of the (greater) freedom made possible by contracting. Second, and more important, because positive private law is a state-provided service, the state is entitled to provide it on its own terms, which may include (among other things) taking

34 Most famously R.C. Ellickson, Order Without Law: How Neighbors Settle Disputes (Cambridge: Harvard University Press, I99I); L. Bernstein, 'Opting Out of the Legal System: Extralegal Contractual Relations in the Diamond Industry' (I992) 2 I J Legal Stud II 5. Both authors, by the way, make normative (and more specifically consequentialist) arguments in support of their claims. More generally, for the claim (from a libertarian) that law undermines interpersonal relationships see L. Ribstein, 'Law v. Trust' (200I) 8I BU L Rev 553.

${ }^{35}$ For a clear example consider the diamond trade discussed in Bernstein, $\mathrm{n} 34$ above.

${ }^{36}$ Cf T.C. Schelling, The Strategy of Conflict (Cambridge: Harvard University Press, I960) 43. This has interesting implications for the discussion on coercion in H.L.A. Hart, The Concept of Law (Oxford: Oxford University Press, 3rd ed., 20I 2) 27-28, but I will not explore them here. 
distributive considerations into account. That is exactly what the state does when, as a matter of unquestionable legal doctrine, it refuses to provide its assistance to the enforcement of certain contracts that are unimpeachable from a purely commutative perspective. Those unhappy with this service, can (and do) resort to other, more private means of enforcement: Knowing that the state will not provide its enforcementservices for his agreements is why the contract killer relies on other means for making sure he is paid.

\section{Does Beever's View Match Legal Doctrine?}

I hope what I have said so far suffices to show the inherent weaknesses in the theoretical position Beever has adopted. Beever may still have one card up his sleeve, namely that for the most part the common law continues to adhere to the traditional view. (Beever suggests that American tort law may be an exception: $25 \mathrm{I}$.) Beever makes only a cursory effort to reconcile this claim with the forgetting thesis, though they are clearly in tension. He says the traditional view is intuitive, so even if forgotten 'as theory' $(273)$, it is likely to convince us in practice (which confirms rather than resolves the tension) and that 'those who created [private] law consciously did so in terms of commutative justice' (273) (which neglects the possibility that the law may have changed). Be that as it may (and especially so as I have argued the forgetting thesis is false), in this section I will examine Beever's exposition of the traditionalist conception of negligence law to see if it matches legal practice.

Unsurprisingly, Beever thinks the modern view cannot explain the law, although it is not initially very clear why. He begins by stating that 'the modern view struggles even to begin to understand the basic nature of the law. Things start hard and get increasingly more difficult' (244). But only a few pages later we read that the modern view, as represented in Judge Andrews's dissenting opinion in Palsgraf, 'seems to be entirely principled. It generates its conclusions by applying a valid conception of wrongdoing, a conception with which we are entirely familiar' (247).

So where is the problem? Beever's makes three kinds of claim. The first problem with the modern view is that it offers no rational basis for limiting negligence liability. To illustrate his point Beever tells the (fictional) story of one Hans Patschert who carelessly injured Adolf Hitler's future mother; Hitler's future father happened to pass by and offered his help. In this way Hans caused the couple to meet, Adolf Hitler to be born, and by a complex yet unbroken causal chain all the destruction brought about by World War II. The modern conception, Beever says, 'causes us to say quite incredible things, such as that the reason Hans is not liable for the Second World War is that adopting that kind of approach would lead to a flood of claims that would overwhelm the courts' $(252)$. For this reason the modern view is bound to limit liability on seemingly arbitrary considerations like the fact that defendants are 'not wealthy 
enough' and therefore heavy liability could 'destroy [them] financially, which would be unfair' (250).

Beever does not cite a single modern author actually endorsing anything like the kind of reasoning in a case like Hans's. Instead he presents this conclusion as following from Judge Andrews's dissent in Palsgraf. As Andrews's dissent is considered a weak decision by many defenders of the modern view, ${ }^{37}$ it is hardly the most reliable place to look for a restatement of it. It is perhaps for this reason that the modern view of tort law as described by Beever is one that many modernists will find hard to recognize as their own.

When properly analysed, there is a straightforward reason on the modern view why Hans could not be made liable for the losses of World War II. According to one popular version of the modern view, a person is negligent (roughly) when the costs of eliminating a risk are lower than the expected loss. The question that this formula does not address, however, is how risks should be individuated. Is the risk of injuring someone due to careless cycling the same risk as that of starting a war? If it is, then the fact that the risk did not materialize in the specific way predicted is considered irrelevant, and as long as the costs of eliminating the overall risk are lower than the expected loss, liability will be imposed (subject to limitations on remote losses). If the risks are treated separately, then the reason why Hans would not be liable for the war is that the probability of his actions starting a war was so minute that he did not have to take any precaution to eliminate that risk in addition to the one he had to take to prevent injury to nearby pedestrians.

The important point to note is that on this question the modern and the traditional view are on equal ground. When Beever turns to explain the traditional view he treats the risk of injury from careless riding of his bicycle and the risk of a war as two separate risks $(25 \mathrm{I})$, but there is nothing that stops us from saying the same if we accept the modern view. As risks can be parsed in different ways, there is no logical basis for deciding one way or the other, and neither the traditional nor the modern view can be said to imply a particular answer to this question. The supposed advantage of the traditional view is entirely the result of Beever's different way of individuating risk-broadly in the case of the modern view, narrowly in the case of the traditional view. ${ }^{38}$

${ }^{37}$ See e.g. R.A. Posner, Cardozo: A Study in Reputation (Chicago: University of Chicago Press, I990) 45 (calling the dissent 'inept'); W.L. Prosser, 'Palsgraf Revisited' (I953) 52 Mich L Rev I, 7 (arguing that both majority and dissent 'beg the question shamelessly').

${ }^{38}$ For an illustration from actual case-law, consider Doughty v Turner Manufacturing [I964] I QB 5 I 8 (CA). Beever supports the outcome of this case (257-258), which puts him, I think, in a very small minority, not least because Doughty is probably not good law. See Jolley v Sutton London Borough Council [2000] I WLR I082 (HL), a decision Beever does not mention. (Interestingly, Doughty was cited during oral argument in Jolley, ibid, I083, but was ignored by the law lords.) These cases provide an illustration of the point made in the text. To reach the conclusion that the defendant in Doughty is not liable, Beever, like the Court in Doughty, has to assume that the 
There is an additional sense in which limiting liability requires a policy judgment, which once again, equally affects the traditional and the modern view. Imagine Helen was injured in her feet due to the negligence of another. Imagine now that a year later, while she was walking in her home, Helen suddenly felt weakness in her feet and fell over. As she was falling, she involuntarily hit an antique vase, which also fell to the ground and was damaged beyond repair. There is incontestable medical evidence that the weakness Helen felt was exclusively caused by the accident. There is no question that Helen is entitled to compensation for losses resulting from her physical injury, but is she entitled to damages for the lost vase? If Helen had been carrying the vase in her hands at the time of the original accident resulting in similar damage to the vase, she would have been entitled to compensation for both her physical injury and her vase. Does the fact that the injury and the loss of the vase took place at different times make a difference? And what if the fall happened while visiting a friend's house, damaging his vase, would the friend be entitled to sue the original tortfeasor for the lost vase? All these are questions about the scope of liability from one risk and the traditional view in no way gives a more principled answer to them than the modern view.

The second problem Beever sees in the modern view is that it offers only implausible and difficult explanations for various legal doctrines. He gives the case of the limits on liability on pure economic losses as an example. The traditional view, he says, has a straightforward explanation to cases of pure economic loss, so much so that Beever thinks that such cases are 'a mere pseudo-problem created by the modern conception' (263): in cases of pure economic loss, no right of the plaintiff has been violated, and therefore she has no claim. That this is not a mere pseudo-problem can be seen from the following scenario: imagine a driver who carelessly drives his car into a building where two restaurants are located. One restaurant suffers light physical damage while the other remains unharmed. However, as a result of the event, there is now risk of structural instability to the old building which requires reinforcement work that forces the two restaurants to be shut for three weeks. The first restaurant could get full compensation for all its losses, both the tiny physical harm and the significant economic loss; the second restaurant will get nothing.

To dismiss the claim of the restaurant-owner who suffered only economic loss because no right of hers was violated is question-begging. Holmes has long ago complained of 'decisions...[which] often are presented as hollow deductions from empty general propositions...or else are put as if they themselves embodied a postulate of the law and admitted of no further deduction, as when it is said that, although there

anticipated and materialized risks were different, which is done by individuating risks narrowly. Jolley reflects a different approach, one that favours risks individuated broadly. See ibid., I093. As I say in the text, I do not think there is anything in the traditional view itself that sanctions narrow parsing of risks, but if (as Beever thinks) there is, that suggests the traditional view does not match current English law. I should add that though modern English law seems to favour broader risk categories, there is no doubt that it would treat the risk of physical harm and the risk of starting a war seventy five years hence as distinct risks. 
is temporal damage, there is no wrong; whereas, the very thing to be found out is whether there is a wrong, and if not, why not ${ }^{\prime}{ }^{39}$ I see no reason why the restaurantowner cannot claim a right against other individuals that they do not carelessly harm her ability to make a living. If this sounds excessively casuistical, too artificiallytailored to fit the conclusion, the same must be true of many other rights that must exist for Beever's view to hold. If the tort of deceit protects the right not to be lied to when the lie causes a (typically economic) loss, then the right I suggested can similarly exist. In any event, to answer this question requires answering the question what rights we have, and that is definitely not a 'pseudo-problem'. Among writers who defend this rights-based view of tort law, the assumption seems to be that the question what rights we have has an obvious and uncontroversial answer. It is not. ${ }^{40}$

Another difficulty with Beever's response is that the tiny physical damage seems insignificant to justify such a different outcome. Even if one accepts that compensation should be limited to a violation of rights, why should economic losses be fully compensated when they are accompanied by physical harm? Beever answers that this is because in such a case the additional economic 'losses are consequences of the defendant's violation of the plaintiff's rights' (263). The traditionalist now faces a dilemma: if all economic losses are compensable when they are accompanied by some physical harm, then the traditional approach leads to an outcome many would find outrageous (think of the difference between the two restaurants). If not all losses that are considered the consequence of the defendant's violation of the plaintiff's rights are compensable (think of Hans), then the traditional view lacks a principled limit to liability, exactly what was supposed to be its advantage in comparison with the modern view.

The third problem with the modern view according to Beever is that it does not match the way legal doctrine analyses negligence cases. I will argue that the opposite is the case: the traditional view, at least as Beever presents it, strays far from standard negligence liability analysis. To show the affinity of the traditional view to legal doctrine Beever relies on Cardozo's opinion in Palsgraf, which Beever treats as an exemplary display of private law adjudication..$^{41}$ I will argue that Cardozo's opinion, as

${ }^{39}$ O.W. Holmes, Jr., 'Privilege, Malice, and Intent' (I 894) 8 Harv L Rev I, 3.

${ }^{40}$ See D. Priel, 'That Can't Be Rights' (2OI I) 2 Jurisprudence 22.

${ }^{41}$ Beever calls Cardozo's decision in Palsgraf 'brilliant' (254) and considers Cardozo as 'perhaps the greatest tort judge of all time' (253), a hyperbolic assessment he bases on, at most, three decisions. Given such accolades, it is worth pointing out that Cardozo saw no difficulty in following the modern view in relying on consequentialist, societal, and policy considerations in his tort decisions. See e.g. Ultramares Corp v Touche, (I93 I) I74 NE 44I, 444; Adams v Bullock, (I9I9) I25 NE 93, 94; Hynes v New York Central Railway Co, (I92I) I3 I NE 898, 900. Cardozo later explained his decision in Hynes by appeal to the judge's 'conception of the end of the law, the function of legal liability'. B.N. Cardozo, The Growth of the Law (New Haven: Yale University Press, I924) Ior. This was no one-off aberration. He also explained the majority's decision in Riggs v Palmer, (I889) I I 5 NY 506 in terms of 'the social interest served by refusing to permit the criminal to permit by his crime'. B.N. Cardozo, 
read by Beever, is very different from existing legal doctrine. On familiar analysis, the duty of care requirement is a question of law that seeks to ascertain whether people who belong to the class of the defendant owe a duty of care to people who belong to the class of the plaintiff. In this case, the answer to this question should have been plainly affirmative. Palsgraf bought a ticket for the train and was, with permission, on the railway's premises. This should have been enough to settle the question of duty of care. For Palsgraf's claim to fail, therefore, the railway should have shown either that the duty was not breached or that the harm as occurred was too remote. As Cardozo explicitly rejects the latter possibility, ${ }^{42}$ the most plausible interpretation of his decision is that he thought that though duty was owed to Palsgraf, it was not breached (even if duties owed to others were breached). This reading fits Cardozo's decision, because his no-liability conclusion seems to turn on the particular, and somewhat unusual, facts of the case.

Beever understands the decision to say that Palsgraf 'was not owed a duty of care' (254), but that is unlikely. There is no question that if the scale had been moved by railway employees earlier that day, carelessly left at a precarious state and happened to fall on Palsgraf exactly as she was walking past it, her claim would have been successful. Since in both this hypothetical and the real case there was carelessness on part of the railway employees which ended up with the scale falling and injuring Palsgraf, Beever's claim that there was no duty of care must be based on something that would distinguish the two scenarios, namely the particular way in which the harm materialized, which is very different from how determinations of duty of care are made.

That, however, is precisely what Beever does. To reach his conclusion, Beever explains his no-duty reading by an unusual, and thoroughly non-traditional, analysis of the different elements of negligence. His analysis blends the question of duty, which is a fairly abstract general question of law, with the question of breach, which is a very

The Nature of the Iudicial Process (New Haven: Yale University Press, I92I) 43. In these extrajudicial writings Cardozo wrote at length of the place of 'utility' and 'social welfare' among the considerations judges do (and ought to) factors take into account in developing the law. See e.g., ibid, Lecture III, especially at I I2-II3. It turns out, then, that like the others Beever hails as purveyors of the traditional view, Cardozo was far less doctrinaire in his adherence to the traditionalist creed.

It is also worth pointing out that though Beever is not alone in thinking of Cardozo's opinion in Palsgraf as an almost superhuman achievement of perspicuity and illumination, admirers of the decision cannot quite agree on what that decision actually said. Contrast Beever's view that Cardozo concluded there was no duty of care owed to Palsgraf with the view in B.C. Zipursky, 'Rights, Wrongs, and Recourse in the Law of Torts' (I998) 5 I Vand L Rev I, 8, who interprets it as a no-breach case. Weinrib, n 45 above, is unclear on the matter, although his reading is evidently not in line with Cardozo's. For Weinrib (just as for Beever) the questions of duty and remoteness are governed by the same standard, that of foreseeability. Ibid., I65. Cardozo, on the other hand, 'assume[d], without deciding' that directness was the appropriate standard for remoteness. See Palsgraf, n 27 above, Ior.

${ }^{42}$ Palsgraf, n 27 above, Io I. 
context-specific and particularized question of fact, and then throws the question of remoteness into the mix as well. According to Beever, the point of [the examination of standard of care] is to determine whether the defendant created an unreasonable risk and was therefore negligent. But on the traditional view, the [duty of care] follows from the [standard of care]. This is because, through the eyes of commutative justice, the creation of an unreasonable risk by a defendant can be a wrong to a particular plaintiff only if that risk was a risk to that person. [257, emphasis added.]

Beever then adds that on the traditional view the question of remoteness 'also follows from [the question of standard of care]. A risk is unreasonable only if it threatens a certain kind of injury or injuries' (257).

All this is very different from black-letter legal doctrine. For example, on this analysis, it makes no sense to say that someone behaved carelessly (below a certain required standard) but is nonetheless not liable because she did not owe a duty of care. Incidentally, Beever's treatment of the question of remoteness reveals, yet again, how the traditional view has no logical means for controlling liability in any more principled way than the modern view for there is no conceptual truth as to what counts as a 'kind' of injury. One can define them narrowly, treating a burn as a different kind of injury from the injury resulting from being hit by a blunt object; one can define them broadly, classifying all physical injuries as a single kind; or one could define them more broadly still by arguing that advances in medical science show that mental injuries are really physical injuries and that therefore even they belong in the same kind of injury. This view would be an anathema to Beever, but it has some support in cases he does not mention. ${ }^{43}$ My point is not that the cases are right and he is wrong, but that there is nothing that can decide this question in a principled way. The only sense in which Beever is wrong is that his preference for narrow categories for kinds of injury is out of line with the cases.

The more significant point is that in collapsing the different doctrinal elements of negligence Beever ends up close to the ultra-modern Lord Denning. ${ }^{44}$ Where a big difference still remains between Denning's and Beever's positions is on the question of the appropriate method for answering the question of liability. Denning has sought to base the answer to particular cases by placing them alongside other cases of a similar type and trying to evaluate the likely implications of a decision one way or the other on the class of similarly-situated people. This, and nothing more mysterious, is what modernists call 'policy'. By contrast, because traditional analysis limits itself to the

43 See Page v Smith [1996] AC I55; White v Chief Constable of the South Yorkshire Police [r999] 2 AC 45 5, 463, 502, 506; cf Adams v Bracknell Forest Borough Council [2004] UKHL 29, [2005] I $\mathrm{AC} 76$, at [io].

44 Spartan Steel ↔) Alloys v Martin [1973] QB 27, 37 (CA); Lamb v Camden London Borough Council [I98I] i QB 625,636 (CA). 
particular case, its proponents must decide the question of the scope of liability on nothing more than a gut feeling. That is indeed what traditionalists advocate. ${ }^{45}$

The first approach is clearly distributive, at least in its implications: it determines the respective rights and obligations of classes of individuals and thus affects their respective wealth. The second may seem not to be so, until one remembers that court decisions have precedential force that affects the behaviour of classes of individuals, and so if the first approach has distributive effects, the same is true of the second. The remaining question is whether when deciding such questions one should say so openly and seek data on the matter, or whether one should hide this fact and rely on intuition. At first glance one would think it obvious that the former approach is superior, but traditionalists' support for the latter helps highlight their oft-hidden politics. This provides a natural link to the final topic I will address in this essay.

\section{Beever's Politics}

Beever's arguments fail as an attempt at 'understanding' the law and politics of our times, because he ignores almost everything that is relevant for understanding them. What he is unhappy about is not the prevalence of an 'idea' (2), it is the reality built on the foundations of this idea. If we are to make sense of the book, it is not as an attempt at understanding, but as a work of political advocacy. This seems to be a latent theme in the book (e.g., I04) mostly hidden under a veneer of conceptual analysis. It is only in the final pages of the book, as though Beever could no longer contain himself, that his politics become explicit. The modern view, Beever strongly suggests, leads to totalitarianism (289-29I). To demonstate just how far we have already gone down that road, in an essay published shortly before Forgotten Justice and that can be read as a précis for it, Beever has noted that ours is the age of 'human resources' as proof of the manner in which the modern view has made us treat our fellow humans. ${ }^{46}$ In that essay Beever candidly said he hoped his ideas would be 'politically transformative (47 $^{\prime 4}$ and for that end in Forgotten Justice he quotes from Joseph Goebbels and from Che Guevara (290-29I, 308-309) as warning signs for where we are headed, the impending

${ }^{45}$ Contrast Lord Denning's approach in Lamb with Watkins LJ's 'instinctive feeling', ibid, 647. For other traditionalists' support for intuition over data. See E.J. Weinrib, The Idea of Private Law (Oxford: Oxford University Press, rev ed, 20I2) 2I9-22I; R. Stevens, 'The Conflict of Rights' in A. Robertson \& T.H. Wu (eds), The Goals of Private Law (Oxford: Hart, 2009) I39, I64 (conflicts of rights should be resolved not by examining 'wider social policies' but by 'judgment').

${ }^{46}$ See Beever, n 6 above, 87. In response to such allegations it is worth noting that almost all the theorists whose ideas Beever thinks would be a bulwark against present-day horrors were supporters of humans being treated as property. Plato, Aristotle, Cicero, Aquinas, and Pufendorf (but not Kant) all endorsed slavery. Bentham, Sidgwick and virtually everyone in this age in which 'individuals are encouraged by the law to think of other individuals as resources to be used for their ends', ibid, reject it.

\footnotetext{
${ }^{47}$ Beever, n 6, 87 note 82 .
} 
eradication of the individual under the crushing yoke of an all-consuming state. ${ }^{48}$ It is not just the future, though: already 'our forgetting of commutative justice' has 'led us to ignore the importance of interpersonal freedom, to overplay the needs of the community vis-à-vis the autonomy of the individual, and to overemphasize the importance of the state and overestimate its ability to facilitate justice' (309). In the same vein, in the earlier essay Beever also said that '[h]uman rights law is the ambulance at the bottom of the cliff. We need it in part because the fence at the top, constructed in no small part by the private law, has been torn down. But it is worse than this, as that law now encourages people to fall down' ${ }^{49}$

Though Beever seeks to present these concerns as ones shared by many on the left and the right (309), Beever's politics are difficult to mistake-the desire to protect the individual from the overpowering collective; the belief that the foundations of political community are based on natural law; the view that private law should largely reflect those natural laws; the view that respect for 'traditional' private law is necessary (and perhaps sufficient) for a well-functioning society; the narrow and inegalitarian understanding of distributive justice; the concern that modern private law has been infiltrated by 'alien' public concerns, which in turn is but one manifestation of a more general encroachment of our freedoms by the state; the claim that people tend to overrely on the state; the insinuation that seemingly innocuous Western welfare states have taken the march down the road to serfdom; Beever's (and other traditionalists') preference for intuitive decisions and the objection to any attempt at evaluating the consequences of a decision, fits with Hayek's preference for small-scale common law adjudication as a form of spontaneous order that is superior to any form of planning; ${ }^{50}$ Beever even says people have no duty to rescue strangers ${ }^{51}$ - these are all familiar libertarian themes. ${ }^{52}$

48 This makes for a nice contrast to communitarian complaints that modern liberals are responsible for the excessive individualism and soulless 'atomism' of our age. Liberals, it seems, can't win.

49 Ibid 86. Here Beever echoes the claim that the 'compensation culture', exemplified by an overly protective tort law and an exceedingly expansive liability of public authorities, can lead to moral decline. See Gorringe v Calderdale Metropolitan Police, [2004] UKHL I 5, [2004] I WLR I057, [32]; Tomlinson $V$ Congleton $B C$ [2003] UKHL 47, [2004] I AC 46, [8I] ['The pursuit of an unrestrained culture of blame and compensation has many evil consequences and one is certainly the interference with the liberty of the citizen'). There is, however, little empirical evidence to support this claim. See R. Lewis et al, 'Tort Personal Injury Claims Statistics: Is There a Compensation Culture in the United Kingdom?' (2006) I4 Torts LJ I 58.

${ }^{50}$ See A.I. Ogus, 'Law and Spontaneous Order: Hayek's Contribution to Legal Theory' (I989) I6 JL \& Soc'y 393, 396-398; T. Zywicki \& A.B. Sanders, 'Posner, Hayek, and the Economic Analysis of Law' (2008) 93 Iowa L Rev 559, 565-569.

51 'If [a drowning] child is not mine, then she has no right against me that I rescue her' (272-273).

${ }^{52}$ Beever complains that 'libertarian views fail sufficiently to acknowledge the need to protect interpersonal independence' (292). This, if I understand him, is the view that in protecting interpersonal freedom we must not neglect to protect it from attacks by other individuals, not just 
Beever is entitled to his political opinions, but it would take a very different book from the one he has written to try to persuade those who do not share his views to adopt them. Since Beever does not argue for these views, I will not discuss here the merits or demerits of libertarianism. Absent a political argument, one would have expected at least some empirical evidence to support his prophecies of imminent doom. There are lots of sheep in New Zealand, but not, to my knowledge, any evidence that New Zealanders have become more sheep-like in their blind adherence to government or less caring of each other since they adopted their social accident compensation scheme. The U.S. provides another example. Beever mentions it as a country where the distinction between public law and private law is not dominant (I70), and with private law more politicized than elsewhere (25I).53 On his analysis that must mean that the U.S. is further down the totalitarian road than the rest of the common law world. There is, as far as I can tell, no evidence to support that.

The most comprehensive challenge to Beever's claims comes from the statistics mentioned earlier on the decline in human violence in exactly those times and places in which the state has been an active presence, a decline made all the more remarkable by the fact that population density is much higher now than in the past. The data themselves are overwhelming and difficult to dispute, but unless shown to be wrong, Beever would have to challenge the causal connection between the rise of the state and the decline of interpersonal violence. Doing so would present Beever with a dilemma: if the decline in violence can be attributed, even in part, to the state, then he is wrong to say that people 'overemphasize the state and overestimate its ability to facilitate justice' (309); quite the contrary, most people, perhaps because they are unfamiliar with the alternative, do not appreciate just how much the state is responsible for their peaceful lives. If on the other hand this decline has nothing to do with the state, then the most likely explanation is a major improvement in humans' concern for interpersonal relationships, which would suggest his worries are unfounded.

\section{Conclusion}

It is sometimes useful to take a step back from a theory, not just to point out its logical inconsistencies, hidden assumptions, or unwarranted conclusions, in order to consider its overall message. Sometimes this more panoramic view can reveal what closer inspection misses out. When one does that, one of the striking features of Beever's

the state. But this is exactly in line with libertarian (as opposed perhaps to anarchist-libertarian) views. See R. Nozick, Anarchy, State, and Utopia (Oxford: Blackwell, I974) II3-I I4. Details aside, Beever's views are in line with the political underpinnings found in the work of other tort law nostalgics. See D. Priel, 'Torts, Rights, and Right-Wing Ideology' (20 I I) I9 Torts LJ I.

${ }^{53}$ Beever contrasts this to the rest of the common law world, where he claims this distinction is deeply ingrained. But this is a mistake: it is in fact a modern development, and as I argue elsewhere, it has been the product of politics, not any conceptual truth. See Priel, n 33 above. 
position is just how strange it is. This is perhaps clearest in the position he takes towards the place of consequences. In contemporary moral philosophy a view is usually classified as non-consequentialist when its proponents think that consequences are not the only thing that matters, that sometimes other, 'deontological', considerations (sometimes called side-constraints) override concern for consequences. What is remarkable about Beever's approach (along with that of other private law nostalgics) is that he thinks that in the domain of private law consequences never matter, that it is never right for humans to choose certain rules over others because they will improve their lot. Contrary to Beever's claim that this is the 'traditional' view that all philosophers used to accept and that this is the view that most people intuitively accept, this extreme view has very few adherents. ${ }^{54}$ Why would they?

Note again that even if one accepts that the foundations of political authority must be grounded in certain non-consequentialist moral considerations that just 'exist', that more concretely, the social contract is binding because of pre-political, purely interpersonal norms, it in no way follows that contract law should simply imitate those norms. Nor does it follow that society may not choose other rules for its positive contract law, if it believes such rules could lead to better consequences. To think otherwise is to adopt a theological view of law, according to which True Private Law descends on us from heaven and what we need to do is 'discover[] and develop[]' (284) what it demands of us through conceptual or doctrinal analysis, and then follow. If doing so leads to consequences we find undesirable, well, dura lex, sed lex. This attitude is reflected in Beever's discussion of a wrongful life claim of a child born with 'catastrophic disabilities' (283). Beever argues that such a claim should be dismissed for the sole reason that 'she had no right not to have been born' (284). There is no recognition that there may be valid considerations in favour of imposing liability (better treatment in the future, concern for the plight of the family involved, preference for the innocent over the negligent, and, yes, also distributive justice) that are utterly ignored by the facile assertion regarding her rights. By relying on concepts developed when the technology that makes such claims possible did not exist, Beever ignores all these considerations.

The practical effect of this view is that humans cannot change the law to fit their interests and changing environment, because, apparently, it is stronger than them. The only way to make sense of Beever's view is if he thinks that what (he thinks) commutative justice demands is the right decision, that all-things-considered people in this child's situation, should not be compensated, that society would behave

54 See O. Johansson-Stenman, 'Are Most People Consequentialist?' (2012) I I 5 Economic Letters 225; J. Greene, 'The Secret Joke of Kant's Soul', in W. Sinnott-Armstrong (ed), Moral Psychology: Volume 3, The Neuroscience of Morality (Cambirdge: MIT Press, 2008) 35. One need not endorse Greene's normative conclusions to accept his empirical findings about the place of consequences in moral reasoning. 
immorally towards someone if it forced him to pay damages in such a case. If this is so, then in presenting his arguments as 'conceptual', Beever tries to win a normative argument without bothering with a normative argument. If, as Beever says, commutative justice is a form of justice, it remains an open question whether we should try to have laws conforming to that form. Put differently, even if private law in its true understanding embodies the principles of commutative justice, it remains an open question whether we should have private law. These are the real, political, questions at stake between traditionalists and modernists. Forgotten Justice offers no assistance in answering them. 


\section{Appendix: Beever's Presentation of Past Thinkers}

Early in his book Beever says that his primary intention in writing it was to tell a 'story that was engaging enough to read' (8). But, of course, he intended to do more than that: his story has a moral, and the moral is that we as a society have made a grave error by abandoning the traditional view. For the historical narrative to be relevant to the normative conclusions he wishes to draw from them, Beever needs to be able to show how ideas affect practice, that they have had causal force in changing our practices and are not epiphenomenal to them (or caused by them). That is a 'philosophical' (and to some extent methodological) task. He must also get right the views of the thinkers he discusses. That is an 'empirical' task. I have serious reservations about Beever's arguments on both counts.

I will have relatively little to say here about the first point. Beever has written a book about the power of ideas, about the way ideas can influence practice. Not everyone believes that they do. I am sympathetic to the view that gives causal force to ideas, the one Keynes famously captured in the concluding pages of his General Theory when he said that 'the power of vested interests is vastly exaggerated compared to the gradual encroachment of ideas' ${ }^{55}$ But to count as history, not mere story-telling, the history of ideas, just like any other branch of history, must be grounded in facts. Any account that seeks to show that one thinker 'influenced' another, that a certain term has come to mean something else due to the impact of a philosopher, that the change in the intellectual climate affected practice, must explain how such influences work. Normally one would wish to see some kind of empirical evidence to support claims of influence, because these are causal claims. To be sure, as in other works of history, one cannot expect proof beyond reasonable doubt, but the evidence must be more than mere assertion.

Though Beever's book often talks of 'influences' there is little in terms of supporting evidence. To take one, admittedly extreme, example: Beever says at one point that the fact Plato did not discuss private law in The Republic 'was an epic blunder, because it was an oversight that is in part responsible for our inadequate understanding of political philosophy, justice, and law today' (44). Such a hyperbolic remark, which Beever supports it with no evidence (what evidence could support it?) is illustrative of a cavalier attitude towards the history of ideas, as though unlike other branches of history, here, anything goes.

I am going to spend more space on the second point, to show just how distorted and misleading are Beever's accounts of the philosophers he considers. It is important, however, to understand how the general methodological question and the substantive one are related. Owen Chadwick's remarks are particular pertinent in the present context:

${ }^{55}$ J.M. Keynes, The General Theory of Employment, Interest, and Money (London: Macmillan, I936) 384 . 


\begin{abstract}
Descriptions of historical process often suffer from one concealed assumption...: the assumption that all was well, or at least was plain and coherent, at the point where the process is believed to start; the historiographical sin known as Decline and Fall history; where the writer knows that he is setting out, for example, to describe a steady decline in civilization until he reaches the point which he thinks of as 'the triumph of barbarism and religion', and consequently...must start with an idyllic picture of the hill-top from which men began to slide....A man enquires into a process and postulates an imaginary picture of society before he starts his enquiry in order to make the process easier for him to understand, not just as one thing after another, but as process. ${ }^{56}$
\end{abstract}

Beever offers a slightly different variation on that theme, that of rise and fall. This is not to say that such narratives cannot be true, but what must be remembered is that history is very rarely so neat. I can only speculate, but my guess is that as Beever came to see private law as a story of rise and decline, he became engrossed in the alluring narrative he devised and worked his way through twenty five centuries of history with that story shaping his reading, fitting the works he analysed to his preordained narrative rather than the other way around. Whether or not this speculation is true, the end result consists of highly distorted readings of the work of various thinkers.

The feuds among different interpreters of the work of past thinkers are, of course, not a new thing. For the most part, I do not aim to show that it is possible to read Aristotle or Kant differently. My point is more basic: when reading their texts, Beever has often ignored or supressed passages that, at the very least, call for comment as they appear inconsistent with his the views he attributes to the philosophers he discusses. It is possible that after careful examination these passages can be shown to be fully consistent with Beever's reading, but that needs to be shown, especially if one aims to persuade the not-yet persuaded. One more clarification: In pointing out the differences between how Beever presents, say, Kant or Locke and what they said I do not mean to claim that properly understood they were closeted Benthamites. I do claim, however, that with virtually every one of the thinkers Beever considers, Beever omits crucial details from his presentation of their ideas and that when these details are added, the views of the philosopher in question look quite different from the way Beever presented them. Apart from serving as a warning against relying on Beever's book as a reference book on the thought of the philosophers he discusses, this discussion provides additional support for my claim in the main text of this essay that Beever's forgetting thesis is unfounded. It also serves to highlight the extent to which Beever's treatment of others' works is sometimes unfair, ${ }^{57}$ if not worse. ${ }^{58}$

56 O. Chadwick, The Secularization of the European Mind in the Nineteenth Century (Cambridge: Cambridge University Press, I975) 3.

${ }^{57}$ Here is an example: Beever criticizes Peter Cane for his supposed claim that the distinction between commutative and distributive justice is a matter of numbers. Beever responds that the distinction between commutative and distributive justice is found in the forms of those concepts. That form relates to the types of analysis, not to the number of parties involved' (287). As it happens, in the essay in question Cane does not say that the distinction between the forms of justice depends 
I recognize that what follows can make for a somewhat tedious reading and may seem overly pedantic. But it is necessary for assessing the historical narrative, which in terms of the space given to it, as well as in terms of the significance placed upon it, it forms the heart of the book. If it is any consolation, I can say that despite its length, the discussion below is not comprehensive.

Plato

I will not compare what Plato says to what Beever attributes to him, except for one brief point. To fit his overarching thesis, Beever presents Plato (or at least Plato of The Laws) as a traditional theorist, committed to the idea of interpersonal relations between individuals. Such a view, Beever thinks, must rest on a notion of equality between all individuals. And so, in a truly comical moment, Beever tells his readers that Plato's egalitarianism is 'somewhat hidden by [his] elitism and acceptance of slavery' (45) (and, one may add, by his views on women). I suppose by this standard Ayn Rand is someone whose socialism is somewhat hidden by her libertarianism and her praise for selfishness.

As an illustration of Beever's book unreliability, I will consider in this context one example, not of Plato himself, but of one well-known commentary on him. In his discussion of Plato, Beever cites (but does not quote) Karl Popper's Open Society and Its Enemies exactly once and claims that according to Popper, the 'chief failing' of Plato's Republic was ignoring 'the lesson so clear to us moderns: that power corrupts' (39). ${ }^{59}$ Beever spends some pages attempting show that Plato was well aware of this danger, although it is hard to share his belief that Plato was 'seldom naïve' and not

on the number of parties involved. But if he did, he could count Beever among those who expressed the same view: 'corrective justice and distributive justice are two forms of justice. The former focuses on the relationship between two individuals; the latter on the place of people in society generally'. Beever, n 5 above, 67. See also what Beever says in Forgotten Justice (205).

${ }^{58}$ In what is ostensibly a review of a book by Stephen Waddams, but is for the most part a vehement attack on the modern view, Beever and his co-author state that 'Waddams' fundamental error is to assume that there is "a simple dichotomy in legal analysis between description and prescription"'. A. Beever \& C. Rickett, 'Interpretative Legal Theory and Academic Lawyer' (2005) 68 MLR 320, 322. Here is what Waddams actually wrote: 'It has not been possible...to maintain a simple dichotomy in legal analysis between description and prescription'. S. Waddams, Dimensions of Private Law: Categories and Concepts in Anglo-American Legal Reasoning (Cambridge: Cambridge University Press, 2003/222. I mention this case, which does not involve Forgotten Justice, because it seems to reflect a pattern. As I show below on more than one occasion I found Beever quoting passages in ways that altered the meaning of the quoted words.

59 As the entire first volume of Popper's Open Society is dedicated to Plato's Republic, it is difficult to summarize it in one sentence and identify one 'chief failing' Popper found in The Republic. If pressed, Popper would most likely reply that The Republic is a book was a recipe for a totalitarian government. If asked about a more 'philosophical' failing, Popper would probably have mentioned the book's underlying 'historicism', the view that human history unfolds according to some overarching, pre-ordained pattern. 
wrong about power (39), when Plato's solution (according to Beever) 'can be presented in a single word: education' (40). That sounds extremely naïve, for the whole point of the claim that power corrupts is that it corrupts, that it changes for the worse those who acquire it, even if well-educated. In any case, did Popper miss Plato's discussion of education? Hardly, except that he had a rather less rosy view of it: 'Plato's philosophical education has a definite political function. It stamps the rulers, and it establishes a barrier between the rulers and the ruled'. ${ }^{60}$ It was also, said Popper, aimed at 'indoctrination-the moulding of minds and of souls which...are "to become, by long habit, utterly incapable of doing anything at all independently"'. ${ }^{61}$ Popper also stated that at least nine of Plato's own students and associates became tyrants, suggesting that education did not succeed in their case to prevent power from corrupting them. ${ }^{62}$

Beever concedes that Plato's position was authoritarian, although, he says, 'not for [Popper's] reasons' (43). The real reason was because a running idea in The Republic is that 'the individual is merely a means to the community's ends' (43). Has Popper somehow missed this idea? 'We mean by justice', says Popper, 'some kind of equality in the treatment of individuals, while Plato considers justice not as a relationship between individuals, but as a property of the whole state, based upon a relationship between its classes'. ${ }^{63}$ Even more directly, Popper talked of Plato's 'demand that the individual should observe the interests of the whole, whether this be the city, the race, or any other collective body'. ${ }^{64}$

\section{Aristotle}

Aristotle is central to Beever's story because in his Nicomachean Ethics one finds the first articulation of the distinction between corrective and distributive justice. Of course, that is not precisely what Beever is looking for, as he is interested in an account of commutative justice, a broader idea that aims to cover not just rectification but the whole range of interpersonal relations between individuals. He therefore relies on Aristotle's account of justice in exchange and argues that it belongs to corrective justice (and so one might say that together they make up the domain of commutative justice).

Beever is correct, I think, that as far as Aristotle is concerned corrective justice and distributive justice are independent. But this is because it seems that Aristotle's understanding of distributive justice was very different from the sense the term is used today. In describing its scope he says that it is concerned with 'the distribution of

${ }^{60}$ K.R. Popper, The Open Society and Its Enemies (London: Routledge, 5 th ed., I966) i, I48.

${ }^{61}$ Ibid., i I 32 (quoting Plato, The Laws, 942c).

${ }^{62}$ Ibid., i I $36-$ I 37.

${ }^{63}$ Ibid., i 90. Notice, by the way, how Popper, a twentieth-century writer, talks of justice as a relation between individuals, a view he should not have been able to comprehend.

${ }^{64}$ Ibid., i Ioo. 
honors or wealth or anything else that can be divided among members of the community who share in a political system ${ }^{\prime}{ }^{65}$ Distributive justice in this view is not at all concerned with questions of inequality or of redistribution. It is concerned with the question of the distribution of what can be divided among members of the community, for instance the spoils of war (or as he says, honours). Now, if this is what distributive justice is about, then Aristotle adopts here what I called in the main text of this essay the 'non-overlapping magisteria' view of justice. That would indeed vindicate Beever's claim that for Aristotle corrective and distributive justice are distinct, but at a price: it would render Aristotle's account largely irrelevant for present-day concerns because the prevailing understanding of distributive justice is different. Of course, that this view is prevailing does not make it true and Beever is welcome to argue that that is how we should understand the relationship between the two. But he does not (usually) say so. More importantly, that would mean that to show that Aristotle's account has any bearing on contemporary debates, Beever would have to show first, on normative grounds, that contemporary understandings of distributive justice are all wrong not in their content, but in their very understanding of what distributive justice is about.

There is a further problem, one that is perhaps more significant for Beever's reading, and it touches on the scope of corrective justice. Beever, recall, argues that Aristotle's account of justice in exchange is complementary to his account of corrective justice and that together they make up the domain of commutative justice. The problem is that Aristotle's account of justice in exchange contains elements that do not fit Beever's traditionalism well. Aristotle first rejects the purely subjectivist view of value, which would allow that an exchange is just so long as both parties voluntarily agreed to it. For an exchange to be just, the objects of the exchange need to be of equal value. This requires 'proportionate reciprocity', which allows for an equal value exchange between (to use Aristotle's example) a shoemaker and a house builder. This (as Beever says: 78) looks like an early statement of the so-called 'just price' theory. It is interesting to note first that Aristotle explicitly relies on broad, societal, considerations in justifying it: 'In communities for exchange...this way of being just, [namely] reciprocity that is proportionate rather than equal, holds people together; for a city is maintained by proportionate reciprocity'. ${ }^{66} \mathrm{He}$ goes on to say 'if this sort of reciprocity were not possible, there would be no community'. ${ }^{67}$ Moreover, the link between proportionate reciprocity and community also goes in the other direction. Instead of barter exchange based on a ratio between a certain number of shoes per house '[c]urrency came along' and made 'all items for exchange...comparable'. ${ }^{68}$ And currency, says Aristotle, is a product of the community. Indeed, it is a product of

\footnotetext{
65 Aristotle, Nicomachean Ethics, T. Irwin trans. (Indianapolis: Hackett, 2nd ed., I999) II30aI I $30 \mathrm{Ob}$.

${ }^{66} \mathrm{Ibid}$., I I $32 \mathrm{~b}$.

${ }^{67}$ Ibid., I I 33b.

${ }^{68}$ Ibid., I I 33 a.
} 
(positive) law. He notes that in Greek the words for 'money' and 'law' are etymologically related: currency 'has its name (nomisma) because it is not by nature, but by the current law (nomos), and it is within our power to alter it and make it useless' ${ }^{69}$ On Beever's classification this puts such exchanges in the domain of politics (and of distributive justice), not of commutative justice.

There is more. When Aristotle goes on to explain this proportionate reciprocity, he relies on a 'diagonal combination that produces proportionate exchange ${ }^{\prime 70}$ to explain it. That poses a difficulty to Beever, because earlier he has claimed that Aristotle distinguishes between corrective and distributive justice by analogy to the mathematical distinction between arithmetic and geometric proportions (74). Beever tries to reconcile this difficulty by saying, '[t]hat distributive justice must refer to four things does not show that whenever justice refers to four things that justice must be distributive justice' (78), which is technically true, but quite different from what Aristotle said, when he distinguishes between corrective and distributive justice. After describing justice in the distribution 'of common assets [that] will always accord with...proportion', he goes on to say 'The just in transactions, ${ }^{[71]}$ by contrast,... accords with numerical proportion, not with the [geometrical] proportion of the other species [of justice]'. ${ }^{72}$ Beever knows this passage: in fact he himself cites it several times (64, $67,72,74)$ to demonstrate that for Aristotle corrective and distributive justice are two distinct forms of justice, neither irreducible to the other. But if that is the case, it would follow that for Aristotle proportionate reciprocity (which Aristotle models on geometric proportion) does not belong in corrective (or commutative) justice.

Aquinas

I will only make two brief remarks about Aquinas. First, Aquinas justifies property on consequentialist grounds. ${ }^{73}$ Beever attempts to get around this passage (I I I-I I 2), but his effort is forced. There is, quite simply, no reason to make or accept it unless one starts from the assumption that Aquinas could not have relied on broad societal considerations in justifying private property. If Aquinas believed that the justification of private property belongs completely to the domain of commutative justice and that it is a fundamental conceptual error to justify private property on societal grounds (as Beever thinks) why would he add such a lengthy discussion of the social benefits of private property in the same section in which he seeks to justify private property? That is bound to cause confusion and is likely to make careless readers think that private property does not belong to commutative justice. Moreover, Aquinas explicitly follows

${ }^{69}$ Ibid.

${ }^{70}$ Ibid.

71 I agree with Beever (69) that when Aristotle says 'transactions' he means roughly 'interactions'.

${ }^{72}$ Aristotle, n 65 above, I I 3 Ib-I I 32 a (first emendation by the translator, the second mine).

${ }^{73}$ See Aquinas, Summa Theologica, II-II, Q.66 Art. 2. 
here another supposed traditionalist, Aristotle, who similarly offered a consequentialist argument for private property. ${ }^{74}$ In the case of Aristotle, even Beever probably recognizes that he could not offer a purely commutative justification for property on his behalf, so he silently passes over his discussion of the justification of property. Now, returning to Aquinas, if he thought it wrong to justify private property by its beneficial consequences, why would he mention Aristotle's clearly consequentialist arguments in this context?

The other remark is on the 'just price' doctrine of medieval contract law, already mentioned in my discussion of Aristotle. Beever presents it as supporting the view that contract belongs to commutative justice (78). But the picture that emerges from Aquinas's discussion of it is quite different: 'in each place it behoves the leaders of the city to determine what the just measures of the things sold are, taking the conditions of places and things into account. Hence it is not lawful to disregard such measures as are established by public authority or custom' ${ }^{75}$ Aquinas, incidentally, was not alone. In medieval times 'just price' meant 'current price' as found on the market. ${ }^{76}$ All this is clearly inconsistent with Beever's understanding of contract law as something that involves only 'two individuals getting together' (205).

\section{Hobbes}

In the main text of this essay I criticized the problems with Beever's attribution of the shift from the traditional to the modern view to Hobbes, when according to Beever himself, Hobbes both failed to explain his departure from the traditional view and in fact relied on it. For the sake of that argument I assumed Beever's reading was correct and showed how hard it is to reconcile with his claim that Hobbes has been so central to the supposed forgetting of the traditional view. Here I will argue that Beever is in fact wrong in his reading of Hobbes. Hobbes did provide reasons for abandoning the traditional view, and his theory did not rely on it in explaining the move from the state of nature to civil society. In saying this I may seem to provide support to Beever's claim about Hobbes's influence, but this is not true, because (as I said in the main text of the essayl for all of Hobbes's 'influence' at no point in history did he convince everyone to see the world his way.

What is Hobbes's argument for rejecting natural law as it was understood by those who came before him? Plainly, this is a controversial question, so all I can do is offer what I find a convincing reading of Hobbes's views, and one that explains why his ideas infuriated so many of his contemporaries. To understand Hobbes's views on morality one must understand his overall metaphysical worldview. He is a materialist and a

\footnotetext{
${ }^{74}$ See Aristotle, Politics, I 263 a.

${ }^{75}$ Aquinas, Summa Theologica, II-II, Q. 77, Art. 2.

76 See J.W. Baldwin, 'The Medieval Theories of Just Price: Romanists, Canonists, and Theologians in the Twelfth and Thirteenth Centuries' (I959) 49(4) Transactions of the American Philosophical Society I, 28-29, 75-76.
} 
naturalist. It is for this reason that he reconceives of the natural laws as precepts of reason, as rational means for survival, not as actual binding laws. And either because for humans passions are stronger than reason, or because of the prevalence of prisoner's dilemma-type situations, or both (there is textual support for both), Hobbes believed that these precepts would not be followed in the state of nature. They are in fact merely 'bind[ing] to a desire that they should take place', and as such binding only in foro interno and therefore 'may be broken' ${ }^{77}$ Hobbes thus explains why the natural laws, though 'men use to call by the name of Lawes', they do so 'improperly'. ${ }^{78}$ This means that according to Hobbes there are no natural laws in the state of nature, if such laws are understood in anything like the sense that most other philosophers writing on natural law, both before Hobbes and after him, thought of them. And if there are no natural laws, the traditional view cannot get off the ground. That is enough to show that Hobbes departed from the traditional view as Beever presented it.

What about Beever's other claim, namely that Hobbes relies on the traditional view he supposedly rejects? In one sense the point last made shows that this cannot be true. Hobbes's idea of natural law is so different from what people accepted before him that inevitably his explanation of the transition to civil society must have been different as well. Beever nevertheless insists that Hobbes unwittingly relies on the traditional view. His argument goes as follows: 'According to the traditional view, law gets its content from justice, either directly or because it was created by a body set up in accordance with the demands of justice' (I92). One would think neither can be Hobbes's view because he is clear, and repeatedly says, that 'where there is no Common-wealth, there nothing is Unjust'. ${ }^{79} \mathrm{He}$ adds that 'the nature of Justice, consisteth in keeping of valid Covenants; but the Validity of Covenants begins not but with the Constitution of a Civill Power' ${ }^{80}$ Furthermore, as Hobbes believed that property was the product of civil society and that in the state of nature everyone had a right to everything, ${ }^{81}$ neither commutative nor distributive justice could exist in the state of nature, as there are no property rights on which they could 'operate'.

There is some ambiguity on the matter, but I think Hobbes's view is not simply that whatever is legal is just and whatever is illegal unjust. If the laws of nature are understood as nothing more than what is rational precepts for survival (which is how Hobbes understood them), some things may become laws of nature only in civil society. This, I think, is Hobbes's view with regard to the performance of contracts. ${ }^{82}$ Nevertheless, Hobbes is clear that there is a difference between what the laws of nature and positive law say about binding contract, thus rejecting the view that

${ }^{77}$ T. Hobbes, Leviathan, R. Tuck ed. (Cambridge: Cambridge University Press, student ed., I 996 [I65I]) I IO (ch. I5).

${ }_{78}$ Ibid., I I I (ch. I5).

${ }^{79} \mathrm{Ibid}$., IOI (ch. I5).

${ }^{80} \mathrm{Ibid}$.

${ }^{81}$ See ibid., 90 (ch. I3), IOI (ch. I 5).

${ }^{82}$ See ibid., IOO-IOI (ch. I 5). This is contrary to what Beever says (20I). 
positive law gets its content from justice. According to Hobbes in the state of nature it is rational to obey contracts for fear for one's life, for one gets something (life) in return for something (money).$^{83}$ Hobbes in fact later goes on to say that it is exactly this fear that gets people into commonwealths in the first place, either fear of each other (in the case of commonwealth created by social contract), or fear of the sovereign (in the case of commonwealth created by force) ${ }^{84}$ By contrast, Hobbes is clear that contracts induced by fear are not binding according in civil society, because of the sovereign's say-so..$^{85}$

This is not the place for an evaluation of Hobbes's arguments. It may be that they are unsuccessful, but that is very different from the claim that he does not offer any, or that he relies on the traditional view. How then does Beever maintain that Hobbes relies on the traditional view that law gets its content from justice? He says that Hobbes states that 'equity' and 'distributive justice' mean the same thing, and derives from this the conclusion that according to Hobbes 'law can be given content by justice ("equity") directly' (192). For this argument to work two propositions must be true. First, Beever needs to show that Hobbes believed equity gives content to law ('directly'); and second, that when Hobbes uses the term 'equity' he means by it something akin to what we call justice. But both are false.

Beever quotes from Hobbes and after the quote concludes that '[f]or Hobbes... "distributive justice" has the same meaning as it does for us' (I93), but what Beever says bears no relation to what Hobbes says. Here is the exact passage Beever quotes:

And Distributive Justice, the Justice of an Arbitrator; that is to say, the act of defining what is Just. Wherein, (being trusted by them that make him Arbitrator,) if he performe his Trust, he is said to distribute to every man his own: and his is indeed Just Distribution, and may be called (though improperly) distributive justice; but more properly Equity; which also is law of nature.... ${ }^{86}$

Beever, who in other contexts insists that in reading historical works in philosophy one should focus on ideas and not words, sees Hobbes using the word 'equity' and apparently thinks Hobbes uses the word in the same way contemporary lawyers use the term. But, for one, it is evident that Hobbes seeks to distinguish between equity and distributive justice: equity is 'improperly' called distributive justice. He then goes on to talk about equity (not about distributive justice) and explains what he means by

${ }^{83}$ See ibid., 97-98 (ch. I4).

${ }^{84}$ See ibid., I3 8 (ch. 20). Hobbes believed both forms of commonwealth are valid and that apart from their origin, they are identical. See ibid., I39 (ch. 20). Beever ignores this in his attempt to explain that 'Hobbes is unable to present an amoral account of sovereign authority' (2OI), and more generally that the basis for his third law of nature is moral, not prudential (I99). In reaching this conclusion Beever ignores pretty much everything Hobbes actually says in explaining this law of nature, including his well-known discussion of the fool. See Hobbes, n 77 above, IOI-IO3 (ch. I 5).

${ }^{85}$ See ibid., I39 (ch. 20).

${ }^{86}$ Ibid., I05 (ch. I 5). Beever modernizes the spelling, but otherwise the passages he and I quote are identical. 
it. It is evident that he talks about something very different from what Beever means by justice (commutative or distributive). For Hobbes equity means impartiality. It is for this reason that Hobbes describes equity as 'the justice of the arbitrator'. This is clear also from Hobbes's explanation (which appears in the same chapter) of what constitutes a 'violation of equity': 'Acception of persons, $\pi \rho \circ \sigma \omega \pi \circ \lambda \eta \psi_{i}^{\prime} \alpha^{\prime}$. ${ }^{87}$ These words, whose meaning is now obsolete but clear, ${ }^{88}$ leave no doubt to the meaning Hobbes attaches to equity. When talking of distributive laws, Hobbes clearly talks of something else: laws that 'determine the Rights of the Subjects, declare to every man what it is, by which he acquireth and holdeth a propriety in lands, or goods, and a right or liberty of action' ${ }^{89}$

This discussion also highlights another difficulty with Beever's approach. Beever has set up his dichotomy of commutative and distributive justice in such a way that whatever does not fit what he considers to belong to commutative justice is by default classified as distributive justice. But Hobbes's case provides one example of how constraining is this way of presenting the matter: if we were to classify impartiality within one contemporary category of justice, it would procedural justice, an idea Beever never mentions. And as Hobbes's equity is procedural in nature, it is now clear why Beever fails in the first requirement necessary for his argument to work: these procedural standards of impartiality do not give substantive content to the law.

Locke

There is no clearer example of the way the forgetting thesis skews Beever's historical narrative as in the chapter on Locke. Beever acknowledges that Locke recognized the existence of rights in the state of nature and the content of those rights is exactly of the kind that Beever has in mind. But in Beever's story Locke was writing after Hobbes, and was 'greatly influenced' by his writings (208), so he must already be part of the decline. That is why Locke's work is presented as only 'dimly aware of and utilizes arguments of commutative justice', why Locke is 'groping for the tradition, but [is] unable to find it' (224).

As a historical matter this makes no sense. Locke, of course, knew of Hobbes, but it is not clear whether he ever read his writings, and though he was sometimes associated with 'Hobbism' he rejected that association in no uncertain terms and developed ideas in direct opposition to Hobbes. ${ }^{90}$ Beever attributes Hobbes's influence

${ }^{87} \mathrm{Ibid}$., I08 (ch. I 5). In the same place Hobbes also says: 'He...that is partiall in judgment, doth what in his lies, to deterre men from the use of Judges, and Arbitraros; and consequently, (against the fundamentall Lawe of Nature) is the cause of Warre'. Ibid. See also his related remarks in ibid., I95I96 (ch. 26).

88 The OED defines 'Acception' as 'Partiality, favouritism', and 'Prosopolepsy' as 'Partiality or undue favour shown towards a particular person, or towards people of a particular class, rank'.

${ }^{89}$ Hobbes, $\mathrm{n} 77$ above, I97 (ch. 26).

90 See P. Laslett, 'Introduction' in J. Locke, Two Treatises of Government (Cambridge: Cambridge University Press, student ed., I988 [I689]) 3, 73-74; see also J. Parkin, Taming the 
on Locke to the fact that Locke was a social contract theorist (208). But since the social contract idea did not originate with Hobbes, Locke could have acquired it elsewhere. ${ }^{91}$ (In any event, it is simply not enough to show that two people shared an idea to demonstrate one influenced the other.) Even if Hobbes did have some influence on Locke, there is simply no way reading one author could have obliterated for Locke a tradition of thousands of years. To do that, he would have to ascribe to Hobbes powers much greater than he had, and to Locke feebleness of mind that is hard to reconcile with what we know about him.

To show that Beever was already 'influenced' by the modern view, Beever treats him in a very different way from the way he does with all other thinkers he considers (the contrast with Pufendorf and Kant is particularly striking): he engages in close philosophical analysis of Locke's arguments and finds them wanting. He then, with no hesitation and no evidence, confidently attributes the failure of Locke's arguments to the influence of the modern view: 'writing after the collapse of the traditional conception in England, he lacked the conceptual tools necessary to elucidate his ideas.... He had lost the tools that belong to the analysis of commutative justice. Most obviously, he used arguments of commutative justice, but the term "commutative justice" is to be found nowhere in his arguments' (224).

Notice that Beever does not conclude from his analysis of Locke's argument that the problem lies with the traditional view; nor does he even consider the obvious possibility that Locke simply failed to offer a sound argument for what he thinks is a defensible position. (That would not be a first in the history of philosophy.) Locke's failure is unambiguously attributed to the fact that Locke was already under the spell of the modern view. History does not work this way. To begin, even the most 'influential' writers never obliterate ideas that existed before them. The rise and fall of dominant ideas is slow and gradual, and it is never the case that one idea completely eradicates others, definitely not so quickly. While there is use and value in talking of 'the Enlightenment' or 'the Romantic period', it makes no more sense to think that at any given historical period everyone thought the same than it would make sense to say this of our time. There are in fact numerous examples of the survival of natural law thinking among English and Scottish writers long after Hobbes was dead. ${ }^{92}$

Leviathan: The Reception of (Cambridge: Cambridge University Press, 2007) 365-368 (discussing Locke's attempts to dissociate his account of anything that might smack of 'Hobbism'), 40O-4OI (discussing Locke's unclear acquaintance with Hobbes's work).

${ }^{91}$ On the knotty question of 'influence' in the history of ideas in general, with some pertinent remarks on the alleged influence of Hobbes on Locke see Q. Skinner, 'Meaning and Understanding in the History of Ideas' (I969) 8 History and Theory 3, 24-27; see also G.S. Wood, The Purpose of the Past: Reflections on the Uses of History (New York: Penguin, 2008) ch. I.

${ }^{92}$ On the place of natural law in the work of Scotsmen like John Millar, Thomas Reid, Dugald Stewart, and others (all born long after Hobbes's death) see K. Haakonssen, Natural Law and Moral Philosophy: from Grotius to Scottish Enlightenment (Cambridge: Cambridge University Press, I996) 
Reading what Locke actually says confirms all this. No-one who has no conception of pre-political rights could have written this:

'Tis plain...by the Practice of Governments themselves, as well as by the Law of right Reason, that a Child is born a Subject of no Country or Government. He is under his Fathers tuition and Authority, till he come to Age of Discretion; and then he is a Freeman, at liberty what Government he will put himself under;...the Power that a Father hath naturally over his Children, is the same, where-ever they be born; and the Tyes of Natural Obligations, are not bounded by the positive Limits of Kingdoms and Commonwealths. ${ }^{93}$

For those with lingering doubts Locke says that '[t]he Society betwixt Parents and children...is far different from a Politick Society' ${ }^{94}$ Here are interpersonal relations between parents and children that according to Locke have nothing to do with the state. When turning to the issues that Beever focused on, private law, even a cursory reading of Locke reveals that at least in general outline one finds there all the ingredients of an account that Beever should be sympathetic to. Locke thinks there are natural laws binding in the state of nature, which are grounded in interpersonal obligations we owe to each, and he thinks that the purpose of moving to civil society is to make sure they are properly enforced. ${ }^{5}$ Unlike either Pufendorf or Kant he is clear that private property can be created in the state of nature. In fact, he argues that the main reason why people enter into civil society is the 'enjoyment of their Properties in Peace and Safety'. ${ }^{96}$ The argumentative device he uses for the generation and justification of private property in the state of nature is the famous 'enough and as good' proviso which can be understood as an alternative to the requirement for a political community as a basis for private property. ${ }^{97}$ Furthermore, Locke thinks that the powers of government are limited to the natural powers possessed by individuals in the state of nature and transferred to the government. ${ }^{98}$ As he puts it, legislative power is limited to the 'fundamental Law of Nature being the preservation of Mankind'. ${ }^{99}$ And since legislative power is supreme to executive power, ${ }^{100}$ then the same is true of executive power as well.

chs. 5-8. In England were still found in the work eighteenth century philosophers and lawyers such as Richard Cumberland, Richard Price, Thomas Rutherforth, and Robert Ward.

${ }^{93}$ See Locke, n 90 above, 347 (\$II.I I 8).

${ }^{94}$ Ibid., 322 (\$II.84).

${ }^{95}$ See ibid., 357-358 (§II.I35).

${ }^{96}$ Ibid., 355 (\$II. I34).

${ }^{97}$ See ibid., 29I (\$II.33).

${ }^{98}$ See ibid., 359 (\$II.I36), 38I-38I (\$II.I7I).

99 Ibid., 358 (§II.I 35). Simmons argues (as he admits, controversially) that in Locke's view even in civil society people retain some of their natural powers. See A.J. Simons, On the Edge of Anarchy: Locke, Consent, and the Limits of Society (Princeton: Princeton University Press, 1995) 64-67.

${ }^{100}$ See Locke, n 90 above, 366-368 (§§II.I49-I 50). 
Locke, therefore, should have been Beever's greatest ally. But he is classified as one of the moderns to fit Beever's forgetting narrative. Coming after Hobbes, and being 'greatly influenced' by him, Locke had to reflect the modern view. As this is difficult to do on the basis of the content of what he said, Beever changes tack. As the quote above shows, Beever concedes that Locke actually relies on the idea of commutative justice, but does not use the term. By the same token, however, Locke has forgotten also about distributive justice for that term too is absent from the Two Treatises. The more important point is that in suddenly turning so literal about this issue Beever departs from what he says elsewhere. When Aristotle talks of 'corrective' justice (which suggests that for him that form of justice is merely concerned with reparation), Beever replies that this is not the case (as we have seen, he is probably wrong about this) and exhorts us not to focus on 'dictionary meaning $[\mathrm{s}]$ ' $(75)$. When Kant does not use terms in the way he favours Beever asks us 'not to be distracted by terminology', because we are interested in ideas (I 52). When it comes to Locke, it is suddenly words, not ideas, that matter.

\section{Pufendorf}

Beever tells us that in Germany the distinction between commutative and distributive justice lived longer than in other parts of the West, 'something about which Germans ought to be proud' (205). In support of this claim we read about Pufendorf and Kant, who lived after Hobbes and yet held on to what Beever considers the correct view. Indeed, it is with them that them that traditional view appears in 'fully developed form[]' (7). In Pufendorf more specifically, we find 'one of the most powerful expressions' of the traditional view (I I 8). Beever arrives at this conclusion by not doing what he did with Locke, namely carefully examining their arguments. After all, if Beever is committed to the truth of the traditional view that sees commutative and distributive justice as completely separate, then Pufendorf's and Kant's departures from it, which Beevers mentions (137, I 52, I62) must be mistakes. And yet Beever does not explain where their 'mixed conception' (I37, I62) goes wrong. In fact, quite surprisingly, he seems to think that they had valid reasons for offering such an account. The other difficulty with Beever's account is that the views he ascribes to both Pufendorf and Kant are different in very important respects from their own views as they emerge from their work. In this and the next section I try to demonstrate this.

As if to spite Beever, time and again Pufendorf relies on consequentialist arguments and expounds ideas that are quite different from traditionalist orthodoxy. In response Beever does two things. At times he quotes a problematic passage but then tries to explain away the problematic ideas and show that Pufendorf really adhered to traditionalist orthodoxy; at other times he ignores problematic passages, in some cases stopping a quotation just before the heretical ideas begin.

To get a sense of the way Beever's reading is skewed consider the following example. Beever states that because Pufendorf considers a principle to belong to natural law, it 'precedes the social contract and thus lies outside distributive justice' (I 30 ). But 
Pufendorf apparently does not accept Beever's arbitrary division. He discusses at some length 'the advantage which accrues to mankind from the mutual interchanges of duties', ${ }^{101}$ and only then concludes that 'it is, therefore, a most sacred precept of natural law'. ${ }^{102}$ Beever quotes these words but omits the crucial word 'therefore'. In doing that he gives the impression that Pufendorf could not have considered the social benefits accruing from private property as having anything to do with their justification, when in fact the very point of these words (when read together with the omitted word) was to show the opposite. The problem is entirely of Beever's making: on his account because private property is a natural law, then it belongs to commutative justice, and therefore it cannot be based on a consequentialist, societal, justification. Pufendorf's deriving a natural law from its social benefits shows he had no difficulty in thinking that some things are natural laws because of their societal benefits.

You might think I am making too much of the word 'therefore', but there are other statements that support this view. Pufendorf is clear that 'among those who live in a state of mutual natural law there is a diversity in the rules of this law, some of which conduce to the mere existence of society, others to an improved existence ${ }^{\prime} .{ }^{103}$ Such statements make it plain that he had no difficulty with consequentialist, societal justifications for natural law. Other statements (for example " Mine and thine" were introduced to avoid wars' $\left.\right|^{104}$ show that Beever had no difficulty with consequentialist, society-wide, arguments for property rights.

Central to the traditional orthodoxy is the distinction between loss and wrong. Its contemporary proponents often tell us that unlike the modern view that envisions tort law as concerned with compensating losses (and are therefore obliged to limit liability on arbitrary policy considerations), the traditional view relies on the principled distinction between mere losses and those that are the result of a commission of a wrong. (Section VI has shown this is not exactly right, but we can ignore this matter here.) Alas, Pufendorf seems to side with modern heterodoxy: 'No one should hurt another' he proclaims in italics, and immediately adds 'If he has caused another loss, he should make it good.' ${ }^{105}$ If this is not clear enough, Pufendorf further explains that losses include 'every injury which concerns one's body, reputation, and virtue. And so the word as we use it signifies any hurt, destruction, diminution, or seizure of something which we now possess, or the interception of something which we should have had by perfect right ${ }^{\prime}{ }^{106}$ Beever is aware of the difficulty but remains undaunted.

101 S. Pufendorf, Of the Law of Nature and Nations (Oxford: Clarendon Press, I934 [I672]) 380 (§III.IV.2). Pufendorf quotes Aristotle and Cicero, both traditionalists according to Beever, as earlier proponents of the same idea.

${ }^{102}$ Ibid., 38 I (§III.IV.2) (emphasis added).

${ }^{103}$ Ibid., I I 8 (\$I.VII.7 [82]).

${ }^{104}$ Ibid, 54I (§IV.IV.7, [369]).

105 Ibid., 3 I 3 (§III.I.I [2 I 3]).

${ }^{106}$ Ibid., 3 I 4 (§III.I.3, [2 I 4 ]). 
What Pufendorf really means is that 'an injury...is not defined as a factual deprivation but as a violation of a person's legal rights' (126). To reach this conclusion Beever quotes Pufendorf:

It must be observed...that, inasmuch as a thing may be owed us in two ways, either by a perfect, or by an imperfect obligation, to which a perfect and an imperfect right correspond respectively, damage which another is bound to restore can be done us only in things owed under the first category, but not in things owed us under the second category. ${ }^{107}$

But Pufendorf's distinction here is between perfect and imperfect rights (and duties) not Beever's different distinction between wrongs and losses. Here is how Pufendorf explains his distinction, in words that appear immediately after the words Beever quotes:

for since [imperfect] duties ought to be performed upon a kind of voluntary impulse arising from a man's good nature, and I have no faculty to force him to perform them, it would be improper to claim some injury if I had not been the recipient of such deeds, or to demand compensation for things which I could not expect from another only by way of a voluntary gift. And just as I cannot count as my own such things as I am but capable of receiving, so I cannot complain that I have suffered damage when such things are not forthcoming. ${ }^{108}$

Elsewhere, Pufendorf gives examples of the domain of imperfect duties: it is 'when one comes to the aid of a man with counsel, goods, or personal assistance, and performs a service of piety, respect, gratitude, kindness, or generosity, for those to whom he was obligated to perform the same'. ${ }^{109}$ In short, Pufendorf's distinction is not between wrongs and losses but between losses and non-losses. As I hope it is clear from Pufendorf's examples, this is not a merely verbal difference. ${ }^{110}$

The next question is to explain why people ought to compensate. Since the obligations to compensate belong to commutative justice, and as such exist in the state of nature, for Beever it is very important that the justification for compensation would not relate to any benefit to society. This is, for him, a logical point: at this stage, he says, 'there is as yet no society to benefit' (I27). He assures his readers that Pufendorf shares this view by quoting the following words:

${ }^{107}$ Ibid., 3 I 5 (§III.I.3, [2 I 4 ]).

${ }_{108}^{108}$ Ibid.

${ }^{109}$ Ibid., I I 9 (§I.VII.8, [82-83]).

${ }^{110}$ Interestingly, when Pufendorf talks of imperfect duties he talks 'of this kind of justice', which he distinguishes from the 'particular justice' that governs 'business relations'. Ibid. Now, either 'this kind of justice', if it is to fit Beever's scheme, must belong to distributive justice (as Pufendorf distinguishes it from commutative justice), in which case distributive justice (or parts of it) exists in the pre-political state of nature; or Pufendorf talks here of a distinct, third, form of justice, in which case he cannot count as an exemplary proponent of Beever's view. 
For it is surely a vain thing to have given orders that a person receive no hurt, if, when such hurt befalls him, he must accept the loss at his own cost, while the man who offered him the hurt may enjoy the fruit of his injury in peace and without making restitution. ${ }^{11}$

This sounds properly interpersonal, but this is only because Beever stops the quote here. He does not quote the words that appear immediately afterwards:

For men are so depraved that they will never refrain from hurting each other, unless they are forced to make restitution, nor will it be easy for a man who has suffered some loss to make up his mind to live at peace with another, so long as he has not received proper restitution. ${ }^{112}$

The fuller quote makes it clear that Pufendorf not only relied on 'forbidden' consequentialist arguments, he relied on social consequentialist arguments as justification for the obligation to compensate. To put it simply, compensation is justified because it prevents social chaos.

The real chestnut for Beever is Pufendorf's apparent view that property rights are only possible in civil society, after the establishment of a political community. To counter this, Beever argues that though for Pufendorf 'property rights are possible only in a civil condition, their acquisition is otherwise entirely independent of that condition' (I4O). This, if it makes any sense, is like saying that though planes can fly only with wings, then apart from those wings their flying is otherwise entirely independent of wings. Beever attempts to clarify this by saying that 'though distributive justice makes possible the existence of a system of property rights, the acquisition of such rights, though of course made against the background of distributive justice, relies directly only on commutative justice' (I40). We know this because first acquisition 'pays no attention to distributive justice' (I4O).

Notice first that even the seemingly minor concession to distributive justice is already something that Beever himself does not acknowledge when he later presents his own views on distributive justice, the one he shares with toddlers: in that account distributive justice only plays a role on the question of redistribution, and property law itself only involves 'our relationship to things' (205), not to other members of society. So even if Beever's presentation of Pufendorf's views is accurate, Pufendorf departs here in a fundamental way from Beever's traditionalism. Second, it is hard to make any sense of the claim that though acquisition is 'made against the background of distributive justice' it 'pays no attention' to it. Most importantly, this attempt at salvaging a token of commutative justice within Pufendorf's account of property bears no resemblance to Pufendorf's own views. Here is what Pufendorf says of the move to the civil condition:

[A]fter men decided to depart from primitive community, they assigned by a previous pact to each person his portion of the things open to all, and this by the authority of the head of the family, by general consent, by lot, or sometimes at the choice of the several parties.

${ }^{111}$ Ibid., 3 I 4 (§III.I. 3, [2 I 4 ]).

${ }^{112}$ Ibid. 
As regards the things which did not come under that first division it was agreed that they shall pass to him who occupied them, that is, to him who was the first to take bodily possession of them with the intention of keeping them for himself. ${ }^{113}$

For Pufendorf it is not just that we need society in order to solve the problem of creating obligations against the whole world, it is that it is a societal agreement that is involved with the actual initial distribution of resources. And it is only the further agreement that allows those who take possession over unowned things to acquire property rights in them. It is only against this background that it is possible to tell the story of the act of original acquisition (which is what Beever quotes from Pufendorf) without 'paying attention' to distributive justice. Contrary to Beever's presentation of the rule of acquisition by first possession as proof of Pufendorf's claim that property rights are pre-political and are possible in the state of nature, Pufendorf clearly holds the exact opposite view. Property is a product of the social contract, not a law of nature; and that is true of the rule of first possession ('As regards the things which did not come under that first division it was agreed that they shall pass to him who...was the first to take bodily possession of them with the intention of keeping them for himself'). In short, when Beever says that for Pufendorf 'it is the interpersonal that is primary and the distributive that is secondary' (I45), he states the exact opposite of Pufendorf's view.

Kant

A natural starting point for a discussion of Kant's views would be examining whether he thought that the purpose of law is simply to enforce our pre-political rights. Here is what he says on the matter:

There are...two crimes deserving death, with regard to which it still remains doubtful whether legislation is also authorized to impose the death penalty. The feeling of honor leads to both....The one crime is a mother's murder of her child (infanticidium maternale); the other is murdering a fellow soldier (commilitonicidium) in a duel. Legislation cannot remove the disgrace of an illegitimate birth any more than it can wipe away the stain of suspicion of cowardice from a subordinate officer who fails to respond to a humiliating affront with a force of his own rising above fear of death. So it seems that in these two cases people find themselves in the state of nature, and that these acts of killing (homocidim), which would then not even have to be called murder (homicidium dolosum), are certain punishable but cannot be punished by death by the supreme power. A child that comes into the world apart from marriage is born outside the law (for the law is marriage $\left.\right|^{[114]}$ and therefore outside the protection of the law. It has, as it were, stolen

${ }^{113}$ Ibid., 569 (§IV.VI.2 [388]).

114 Beever ridicules the following statement: 'Marriage [is] the institution regulating sex, reproduction, and family life'. E. Brake, 'Marriage and Domestic Partnership', in Stanford Encyclopedia of Philosophy, available at http://plato.stanford.edu/entries/marriage/. Beever sneers: 'Tell that to my wife' (309). Beever would probably be surprised to learn (or if he knows, ought to explain why he failed to mention) that Kant's view as quoted here is very similar to the modern view he mocked. In addition to the words in the text, Kant also said that 'natural union according to law is 
into the commonwealth (like contraband merchandise), so that the commonwealth can ignore its existence (since it was not right that it should have come to exist in this way), and can therefore also ignore its annihilation; and no decree can remove the mother's shame when it becomes known that she gave birth without being married. [Here I skip Kant's discussion of the duel.] What, now, is to be laid down as right in both cases (coming under criminal justice)? - Here penal justice find itself very much in a quandary. Either it must declare by law that the concept of honor (which is here no illusion) counts for nothing and so punish with death, or else it must remove from the crime the capital punishment appropriate for it, and so be either cruel or indulgent. The knot can be undone in the following way: the categorical imperative of penal justice remains (unlawful killing of another must be punished by death); but the legislation itself (and consequently also the civil constitution), as long as it remains barbarous and undeveloped, is responsible for the discrepancy between incentives of honor in the people (subjectively) and the measures that are (objectively suitable for its purpose. So the public justice arising from the state becomes an injustice from the perspective of the justice arising from the people. ${ }^{115}$

Not everything Kant says here is crystal clear, but what is clear is that according to Kant civil society does not merely enforce pre-political norms. More importantly, Kant attaches utmost significance to the question of whether a baby is born within a legal marriage. If not, he thinks of him as (in some sense) like 'contraband merchandise' and consequently his killing by his mother as possibly unpunishable! Because marriage is something that exists only in civil society, 'the disgrace of an illegitimate birth' can

marriage'. I. Kant, The Metaphysics of Morals (Cambridge: Cambridge University Press, 1996 [I797]) $62(\$ 24[6: 277])$.

More importantly, as in my discussion of private law, it turns out that Beever maintains a public aspect of private affairs that is more significant than his rhetoric would suggest. He fails to notice that marriage, as opposed to cohabitation, does exactly what the words he lampooned say. One may have all the interpersonal aspects Beever presumably associates with marriage (love, companionship, friendship, sex, exclusivity, the raising of a family) completely 'privately' without any ceremony or status. To quote Mil Millington (in response to the question why he and his girlfriend, with whom he was living for more than a decade and had two kids, did not get married): 'You seem to have some kind of confusion that makes a ritual inseparable from the thing it announces. I'm sorry to be the one to break this to you, but if you don't have a funeral, you're still dead, OK?'. See http://www.mil-millington.pwp.blueyonder.co.uk/faq.htm\#married. If marriage goes beyond that, it is in creating a property-like status good against the whole world that goes beyond the interpersonal relation between spouses. As such it suffers from the same difficulties discussed above regarding the creation of private property outside the state.

Incidentally, statistical evidence shows that more and more people these days cohabit without getting married, a phenomenon that is (yet again) hard to square with the forgetting thesis. This phenomenon suggests people increasingly view family life as a purely interpersonal relationship (something Beever suggests they would find inconceivable) rather than as a state-conferred legal status.

115 Kant, n II4 above, I08-IO9 (\$49.E.I [6:336-337]). The passage talks of criminal law, but Beever's view of the foundation of criminal law is similar to his view on tort law $(87-88$, 108). As he puts it, 'criminal law is best understood as strengthening of private law' (88). 
only exist in civil society thus turning a murder into something else: an honour killing. This view is miles away from Beever's traditional view.

Turning to private law, Beever insists that commutative justice can do all the job of explaining property law. This, however, is manifestly not Kant's view:

If one asks what is to be laid down as right in itself (in the state of nature) in the acquisition of external things in accordance with principles of justice in human beings' exchanges with one another (iustitia commutative), then one must answer...[that] even if he has strictly observed the formal conditions of deriving the thing from what belongs to another...as long as he remains ignorant as to whether someone else (other than the seller) is the true owner of it, the most he could have acquired is only a right against the person with regard to the thing. ${ }^{116}$

Kant makes it clear that 'no trade in external things, no matter how well it may agree with the formal conditions of this kind of justice (iustitia commutativa), can guarantee a secure acquisition' ${ }^{117}$ This epistemic problem afflicts original acquisition (which is different from the normative problem of binding the whole world), because in that case too it is always possible that someone else may show up and prove she is the true owner. ${ }^{118}$

On the traditional analysis (which Beever accepts: 205),119 property rights are rights to things (rights in rem) good against the whole world, and as such conceptually distinct from rights against other people. How can a person acquire rights good against the whole world on the basis of interpersonal relations, when she has interpersonal relations only with a minuscule percentage of humans? Kant was aware of this problem, and concluded that property is a product of the state: 'for a unilateral will cannot put others under an obligation they would not otherwise have. - But the condition in which the will of all is actually united for giving law is the civil condition' ${ }^{120}$

What, then, is the solution, necessary for establishing property rights in rem? Kant's answer is clear:

$[\mathrm{R}]$ eason giving laws with regard to rights comes forth with a principle of distributive justice, of adopting as its guiding rule for the legitimacy of possession, not the way it would be judged in itself by the private will of each (in the state of nature), but the way it would be judged before a court in a condition brought about by the united will of all (in a civil condition. ${ }^{121}$

Notice that Kant uses distributive justice in an utterly different way from the one sanctioned by Beever, which is that the role of distributive justice is not to ground

${ }^{116}$ Ibid., 82 (§39 [6:302]).

${ }^{117}$ Ibid., 82 (\$39[6:302]).

${ }^{118}$ Ibid., 55 (§I7 [6:268-269]).

${ }^{119}$ Interestingly, Kant seems to suggest what looks like an early version of the 'modern' bundleof-rights view of property rights. See ibid., 49-50 (§ I I [6:262]).

${ }^{120}$ Ibid., 52 (§I 5 [6:264]).

${ }^{121}$ Ibid., $82(\$ 39[6: 302])$. 
property rights but only to justify redistributing them' (279). Commutative justiceinterpersonal justice-is on this view both necessary and sufficient for explaining our ideas of property: 'we [when not corrupted by the modern view] believe that the money [we get as salary] is ours because of the relationship we have with our employer' (279). And yet Kant is eminently clear that property is a product of distributive justice: 'what is in itself a right against a person, when brought before a court, holds as a right to a thing. A horse, for example, that someone puts up for sale in a public market regulated by police ordinances becomes my property if all the rules of buying and selling are strictly observed...; and what would otherwise be my right against a person is converted into a right to a thing'. ${ }^{122}$

How does Beever deal with this difference between his purely-commutative account of property and Kant's? Beever claims that, '[1]ike Pufendorf, Kant maintains that a system of property rights exists in the state of nature' (I6I). We have already seen this is not true in the case of Pufendorf, and the passages quoted from Kant suggest Beever is wrong about Kant as well. How does Beever overcome these recalcitrant passages? For the most part he simply ignores them. He does admit, however, that, like Pufendorf, Kant too adopts a 'mixed conception' of property (I6I). He then struggles mightily to show that despite what Kant clearly says, he really belongs to the traditional camp.

First, Beever states that 'as Kant rightly identifies, the unilateral act problem [i.e., the problem that a unilateral act cannot create rights against the whole world] is a problem for commutative, not distributive, justice... The problem can be solved only by distributive justice, but that is another matter' (162, emphasis added). But this is not another matter, that is exactly the point: that this is a problem for commutative justice, that commutative justice alone is incapable of grounding property and that distributive justice is necessary for establishing it. This does not show that Kant accepts the traditional view (as Beever defines it): it is all that is needed to show that he repudiates it. Property is not the basis of distributive justice, it is the product of it. Beever's claim that Kant endorsed the traditional view because he showed that commutative justice cannot provide an adequate solution to the problem of establishing property would turn all modern theorists are traditionalists.

Beever's second answer is that

[Kant's] idea is that property would exist in the state of nature were it not for the unilateral act problem. This means that the norms of property law are already in place in the state of nature, though no property can exist there (merely) because the unilateral act problem prevents that occurring. In other words, the unilateral act problem is not a problem with the foundation or structure of property law; it is rather a defeasable [sic] barrier to the actual acquisition of individual property rights. Kant expresses this by saying that property is provisional but not conclusive in the state of nature. [I62.]

${ }^{122}$ Ibid., $82(\S 39,[6: 302-303])$. 
This is hardly better. The passage suggests that for Kant property rights in the state of nature are like a fully-functioning engine, only lacking in fuel to start working; or less metaphorically, it suggests that what is missing in the state of nature is an enforcement mechanism. But this is to misunderstand the nature of the change brought about by the move to civil society. On the traditional analysis Beever endorses, property (and property law) involves a different kind of right from the right than the right created by through contract or tortious injury, exactly because it cannot be grounded in any interpersonal relation between any one person and the rest of humanity (including humans not yet born at the time that the property is acquired). And this according to Kant is a radically different relation than the one found in relations of commutative justice: acquisition based on commutative (contractual) relations 'will always remain only provisional unless this contract extends to the entire human race'. ${ }^{123}$ To put it as simply as possible: property is impossible in the state of nature, because property rights cannot exist in the state of nature.

Beever compounds this misreading of Kant with another by attributing to Kant the distinction between provisional and conclusive property. But that is not what Kant says: Kant distinguishes between provisional and conclusive acquisition, the former being a necessary condition for the creation of property in the civil condition. ${ }^{124}$ As he explains, 'for although each can acquire something external by taking control of it or by contract in accordance with its concept of right, this acquisition is still only provisional as long as it does not yet have the sanction of public law, since it is not determined by public (distributive) justice and secured by an authority putting this right into effect ${ }^{\prime} .{ }^{125}$ Clearly, then, property belongs to public law and it is determined (not merely secured) by distributive justice.

Let me add one additional point. Beever attempts to respond to the arguments of two Kant scholars who have written that 'for Kant all law applicable in [the juridical] state is public law' (r69). ${ }^{126}$ They base this contention on Kant's words: 'The totality of statutes that need to be announced to the public in order to create a juridical state is public $l a w^{\prime} .{ }^{127}$ Beever rejects this view, but it is perfectly in line with what Kant says only a few pages earlier:

A rightful condition [i.e., civil society] is that relation of human beings among one another that contains the conditions under which alone everyone is able to enjoy his rights, and the formal condition under which this is possible in accordance with the idea of a will giving law for everyone is called public justice. With reference to either the possibility or the actuality or the necessity of possession of objects...in accordance with law's public justice can be divided into protective justice..., justice in men's acquiring

${ }^{123} \mathrm{Ibid} ., 53$ (§I 5 [6:266]).

${ }^{124}$ Ibid., 52 (§I $\left.5[6: 264]\right)$.

${ }^{125}$ Ibid., 90 (\$44 [6:3 I 2]).

126 Quoting B.S. Byrd \& J. Hruscka, Kant's Doctrine of Right: A Commentary (Cambridge: Cambridge University Press, 2010) 30.

${ }^{127}$ Kant, $\mathrm{n}$ I I 4 above, 85 (§4I [6:306]). 


$$
\begin{aligned}
& \text { from one another (iustitia commutativa), and distributive justice (iustitia } \\
& \text { distributiva). }{ }^{128}
\end{aligned}
$$

Not only does Kant divide justice into three separate categories (not two like Beever), he states clearly that commutative justice is part of public law. Beever addresses this passage, and is forced (rather lamely) to say that despite all that Kant says in it, 'it remains possible' that Kant adheres to the traditional view (I52). But in a passage Beever does not mention Kant says that though the pre-political stage need not be a stage of injustice, it is 'a state devoid of justice', and that it is exactly for this reason that 'each may impel the other by force to...enter into a rightful condition' ${ }^{129}$ It is amazing that after all this Beever accuses the Kant scholars in question of a 'desire to make Kant's theory fit the modern view' (168).

The broader significance of the discussion of Pufendorf and Kant is worth spelling out: first, the attempt to separate all political philosophers into two camps of 'traditionalists' and 'modernists' is misguided, more distorting than illuminating, because there are simply too many differences between, say, Aristotle, Hobbes, Locke, and Kant, to render any simply dichotomous classification useless. Second, careful reading of Beever's own book, especially when accompanied by reading of the actual works of the philosophers he discusses, shows that not one of the theorists he classifies in the 'correct', traditional, camp actually provides the pure separation of commutative and distributive justice in the way Beever approves of. This does not yet show that Beever's view is wrong, but for a book that seeks to show the dominance of this 'traditional' understanding for almost two thousand years, this is a remarkable finding.

\section{The Utilitarians}

By the time we get to the final stage of Beever's historical story, the decline of the traditional view was apparently in such full swing that we can group together three quite different thinkers and treat them as a 'movement' (227), despite the fact that one of them was born after another had already died. We can do that because, according to Beever, despite their differences 'the utilitarians'-Bentham, Mill, and Sidgwick-'all share[d] the same general understanding of the nature of morality and its connection with politics and law' (227). Moreover, these views were so simple and straightforward that we could discuss them all in the space of thirteen pages.

Just how similar their views were on these matters is clear from Mill's essay on Bentham:

It is fortunate for the world that Bentham's taste lay rather in the direction of jurisprudential than of properly ethical inquiry. Nothing expressly of the latter kind has been published under his name, except the Deontology-a book scarcely ever, in our

\footnotetext{
${ }^{128}$ Ibid., 84-85 (§4I [6:305-306]).

${ }^{129}$ Ibid., 90 (\$44 [6:3 I 2]).
} 
experience, alluded to by any admirer of Bentham without deep regret that it ever saw the light. ${ }^{130}$

Leaving this aside, all three were prolific writers, and yet Beever examines their ideas as they are found in one book (or two mid-size essays in the case of Mill) ignoring altogether their writings that do not fit the role assigned to the utilitarians in his story.

When turning to discuss their ideas Beever claims that 'the utilitarians concentrated on asking how the state-presuming that it is per se just-should treat its citizens. In other words, their focus was on obligation, rather than authority' (228). This claim is tailored to fit Beever's overall story. As prime examples of the age of forgetting, the age in which we see everything through the lens of the state, the utilitarians could not but take the state and its justification for granted. Beever's narrative also implies that utilitarian theory is concerned with citizens, for in this age we have forgotten how to think of others outside the context of the state, so to the extent that we think of others, we only think of fellow-citizens.

Now let us turn to what the utilitarians actually wrote. First, all three wrote on the question of political authority. In the case of Mill, the discussion of state authority is central to one of his writings Beever did consider, 'On Liberty'. The central point of this essay was to consider 'the nature and limits of the power which can be legitimately exercised by society over the individual' (as the opening sentence of the essay proclaims). ${ }^{131}$ The essay does contain a discussion of the basis of state authority, ${ }^{132}$ and its whole point is that the state power may not be used even when it can make someone's life better. In the case of Bentham and Sidgwick, they did write on authority, only not in the books that Beever happened to look at. ${ }^{133}$ The other distortion is more serious: utilitarian theory is the most cosmopolitan there is, as it is concerned with the welfare of humans regardless of their state-affiliation. Mill spoke of 'universal happiness' ${ }^{134}$ Bentham, as usual more verbose, made it clear that the true understanding of the principle of utility crossed national boundaries. Starting with ' $[\mathrm{t}]$ he end of the conduct which a sovereign ought to observe relative to his own

130 J.S. Mill, 'Bentham', in Collected Works of John Stuart Mill (Toronto: University of Toronto Press, I969 [1838]) $\mathrm{x}, 77,98$.

${ }^{131}$ See J.S. Mill, 'On Liberty' in On Liberty and Other Essays (Oxford: Oxford University Press, I99I [I 859 ]) 5,5 .

132 Ibid., 83.

${ }^{133}$ In the case on Bentham, since the ideas are found in various works, it is easier to cite secondary literature. See J.H. Burns, 'Bentham on Sovereignty: An Exploration' (I973) 24 NILQ 399. In the case of Sidgwick see H. Sidgwick, The Elements of Politics (London: Macmillan, 2nd ed. I897) ch $3 \mathrm{I}$ and appendix.

${ }^{134}$ J.S. Mill, 'Utilitarianism', in On Liberty and Other Essays [I863], n I 3 I above, I3 I, I48; see also J.S. Mill, 'Considerations on Representative Government', in On Liberty and Other Essays [I86I], n I3I above, 204, 430, where he describes the view that sees 'so broadly marked a distinction between what is due to a fellow countryman and what is due merely to a human creature' as 'more worthy of savages than of civilized beings'. 
subjects...ought to be the greatest happiness of the society concerned', Bentham insisted that ultimately the correct understanding of the principles of utility is 'the greatest and common utility of all nations taken together'. ${ }^{135}$

Not only was Bentham willing to extend the utilitarian calculus beyond political boundaries, he explicitly stated it should be extended beyond biological ones to include creatures that could never become citizens. In a famous passage he wrote:

The day may come when the rest of the animal creation may acquire those rights which never could have been withholden from them but by the hand of tyranny. The French have already discovered that the blackness of the skin is no reason why a human being should be abandoned without redress to the caprice of a tormentor. It may one day come to be recognized that the number of the legs, the villosity of the skin, or the termination of the os sacrum, are reasons equally insufficient for abandoning a sensitive being to the same fate. What else is it that should trace the insuperable line? It is the faculty of reason, or perhaps the faculty of discourse? But a full-grown horse or dog is beyond comparison a more rational, as well as a more conversable animal, than an infant of a day, or a week, or even a month, old. But suppose they were otherwise, what would it avail? the question is not, Can they reason? nor Can they talk? but, Can they suffer? ${ }^{136}$

When turning to describe basic utilitarian ideas Beever gets them wrong. He treats the desire to maximize utility as a question with an 'obvious application to the individual. If I want to know which of two options I ought to choose and only my happiness is at stake, then I ought to choose the option that maximizes my happiness' (228). There are serious distortions here. The first is that, as Mill was at pains to point out, utilitarianism is not concerned with the maximization of one's own happiness. ${ }^{137}$ Second, although we are getting into somewhat more contentious territory, it is not even clear that for utilitarians 'the Principle of Utility ranges over...the individual and society' (229). This is so for two reasons. One is that it is not at clear that all the utilitarians Beever talks about thought of utilitarianism as a guide for action at all. This may have been Sigdwick's view, but it is not at all clear that this was true, for different reasons, of either Bentham or Mill. There is an important distinction between utilitarianism as a theory for evaluating state of affairs and a theory for guiding action,

135 J. Bentham, 'Principles of International Law', in The Works of Jeremy Bentham, J. Bowring ed. (Edinburgh: William Tait, I 843) ii, 537, 537-538; see also the short discussion in J.R. Dinwiddy, 'Bentham on Private Ethics and the Principle of Utility', in Radicalism and Reform in Britain, I780I 860 (London: Hambledon Press, I992) 315, 317-3 I 8, 335-337.

${ }^{136}$ J. Bentham, An Introduction to the Principles of Morals and Legislation (Oxford: Oxford University Press, I996 [I780/89]) 283, note b (§XVII.4) (sub-footnote omitted). Singer's expanding circle (see note I4 and accompanying text) is premised on similar utilitarian foundations.

137 'I must again repeat, what the assailants of utilitarianism seldom have the justice to acknowledge, that the happiness which forms the utilitarian standard of what is right in conduct is not the agent's own happiness, but that of all concerned.' Mill, 'Utilitarianism', n I34 above, I48. Bentham contains a difficult passage in which he seems to endorse and reject this view. See Bentham, n I36 above, 285 (§VII.8). I consider in the text what I consider the most plausible understanding of Bentham's views. 
and there are good reasons for thinking that both Bentham and Mill thought of utilitarianism in the former sense, not the latter. ${ }^{138}$ It is, further, an open question whether Bentham thought his utilitarianism applied to individuals. It seems that Bentham believed that individuals will simply act to maximize their own (perceived) self-interest (which may sometimes include the interests of others). He therefore conceived of utilitarianism as what Robert Goodin has called, a 'public philosophy'. ${ }^{139}$ It is exactly for this reason that Bentham focused his attention on the design of institutions that would promote the greatest happiness for the greatest number, not on normative ethics.

All this leaves intact the domain of what these writers called 'private ethics' based entirely on interpersonal relations. As discussed in the main text of this essay this is a valid form of 'private law', one more private than the form Beever envisages which is backed up by state coercion. On this understanding the utilitarians can live perfectly happily with the claim that our non-legal interpersonal relationships reflect notions of commutative justice, and still consistently argue that all positive law should be based on society-wide welfare considerations. Beever may disagree, but there is nothing incoherent about this view and it does not involve any forgetting of commutative justice.

Even when citing or quoting from the utilitarians' books, Beever glosses their work in a manner that fits his story more than what they said. Consider, for example, Beever's description of Bentham's view:

According to Bentham...'The general object which all laws have, or ought to have, in common, is to augment the total happiness of the community.' Commutative justice is entirely off the radar. For this reason, though Bentham recognizes that it is commonly thought that wrongs can be done to particular individuals...he maintains that this thought is the result of inadequate reflection. In fact, Bentham tells us, the wrong is social. That is, the wrong is committed against everyone. The victim is a victim, says Bentham, not because she suffers a personal wrong, but because she personally suffered from the wrong. [P. 23I.]

On this view Bentham thought that if I injure someone I commit a wrong 'against everyone'. Is this what Bentham really said? Though he does not quote Bentham, Beever provides a citation. Here is what we find there:

II. The tendency of an act is mischievous when the consequences of it are mischievous; that is to say, either the certain consequences or the probable. The consequences, how many and whatsoever they may be, of an act, of which the tendency is mischievous, may,

138 This was Hart's interepretation of Bentham's view, and it is endorsed and further defended in P.J. Kelly, Utilitarianism and Distributive Justice: Jeremy Bentham and the Civil Law (Oxford: Clarendon Press, I990) 62-70. On Mill see J.S. Mill, Autobiography (Harmondsworth: Penguin, I989 [I873]) II7; Mill, 'Utilitarianism', n I34 above, I48-I52. On the distinction more generally see P. Railton, 'Alienation, Consequentialism, and the Demands of Morality' (I984) I3 Phil \& Pub Aff I34.

139 R.E. Goodin, Utilitarianism as a Public Philosophy (Cambridge: Cambridge University Press, I995). Goodin, correctly in my view, attributes this view to Bentham in ibid., I2. 
such of them as are mischievous, be conceived to constitute one aggregate body, which may be termed the mischief of the act.

III. This mischief may frequently be distinguished, as it were, into two shares or parcels: the one containing what may be called the primary mischief; the other, what may be called the secondary. That share may be termed the primary, which it sustained by an assignable individual, or a multitude of assignable individuals. That share may be termed the secondary, which, taking its origin from the former, extends itself either over the whole community, or over some other multitude of unassignable individuals.

IV. The primary mischief of an act may again be distinguished into two branches: I. The original: and, 2. The derivative. By the original branch, I mean that which alights upon and is confined to any person who is a sufferer in the first instance, and on his own account: the person, for instance, who is beaten, robbed, or murdered. By the derivative branch, I mean any share of mischief which may befall any other assignable persons in consequence of his being a sufferer, and no otherwise. These persons must, of course, be persons who in some way or other are connected with him. Now the ways in which one person may be connected with another, have been already seen: they may be connected in the way of interest (meaning self-regarding interest) or merely in the way of sympathy. And again, persons connected with a given person, in the way of interest, may be connected with him either by affording support to him, or by deriving it from him.

V. The secondary mischief, again, may frequently be seen to consist of two other shares or parcels: the first consisting of pain; the other of danger. The pain which it produces is a pain of apprehension: a pain grounded on the apprehension of suffering such mischiefs or inconveniences, whatever they may be, as it is the nature of the primary mischief to produce. It may be styled, in one word, the alarm. The danger is the chance, whatever it may be, which the multitude it concerns may in consequence of the primary mischief stand exposed to, of suffering such mischiefs or inconveniences. For danger is nothing but the chance of pain, or, what comes to the same thing, of loss of pleasure. ${ }^{140}$

As is evident there is no relation between what Bentham says and Beever's reading. Bentham enumerates the kind of losses that can be suffered from a 'mischief', which include both the ('original') harms suffered by the first victim and the additional ('derivative') harms suffered by particular individuals related to the original suffered. In addition to these Bentham, characteristically ahead of his time, talks here of fear ('alarm') and risk ('chance') as additional harms. So Bentham does not say that all wrongs, even when they appear to affect one individual, are really social. He expresses the utterly different (and unquestionably true) idea that when wrongs are committed, there may be people who suffer distinct and different harms in addition to the harms suffered by the original victim.

Immediately after the paragraphs I have just quoted, Bentham provides an example of what he has in mind:

VI. An example may serve to make this clear. A man attacks you on the road, and robs you. You suffer a pain on the occasion of losing so much money: you also suffered a pain

140 Bentham, n I36 above, I44-I45 (§§XII.2-5) (footnote omitted). Beever's precise citation is to $\S \S X I I .3-4$. I quote a longer passage for clarity. 
at the thoughts of the personal ill-treatment you apprehended he might give you, in case of your not happening to satisfy his demands. These together constitute the original branch of the primary mischief, resulting from the act of robbery. A creditor of yours, who expected you to pay him with part of that money, and a son of yours, who expected you to have given him another part, are in consequence disappointed. You are obliged to have recourse to the bounty of your father, to make good part of the deficiency. These mischiefs together make up the derivative branch. The report of this robbery circulates from hand to hand, and spreads itself in the neighbourhood. It finds its way into the newspapers, and is propagated over the whole country. Various people, on this occasion, call to mind the danger which they and their friends, as it appears from this example, stand exposed to in travelling; especially such as may have occasion to travel the same road. On this occasion they naturally feel a certain degree of pain: slighter or heavier, according to the degree of ill-treatment they may understand you to have received; the frequency of the occasion each person may have to travel in that same road, or its neighbourhood; the vicinity of each person to the spot; his personal courage; the quantity of money he may have occasion to carry about with him; and a variety of other circumstances. This constitutes the first part of the secondary mischief, resulting from the act of robbery; viz. the alarm. But people of one description or other, not only are disposed to conceive themselves to incur a chance of being robbed, in consequence of the robbery committed upon you, but (as will be shown presently) they do really incur such a chance. And it is this chance which constitutes the remaining part of the secondary mischief of the act of robbery; viz. the danger. ${ }^{141}$

It is plain that there is no relation between Bentham's classification of the different kinds of 'consequences of a mischievous act' and in particular his recognition that the class of those who suffer from such acts is often much broader than the primary victim of such acts, and Beever's claim that according to Bentham all wrongs are 'committed against everyone' (23I).

Furthermore, for someone who supposedly did not believe in the existence of a private realm or conceived of relations between individuals only through the lens of the state, it is rather surprising to read Bentham say, elsewhere in the same book:

$[\mathrm{T}] \mathrm{O}$ instruct each individual in what manner to govern his own conduct in the details of life, is the particular business of private ethics: to instruct individuals in what manner to govern the conduct of those whose happiness, during nonage, is committed to their charge, is the business of the art of private education. The details, therefore, of the rules to be given for that purpose, any more than the acts which are capable of being committed in violation of those rules, belong not to the art of legislation: since, as will be seen more particularly hereafter, such details could not, with any chance of advantage, be provided for by the legislator. ${ }^{142}$

${ }^{141}$ Ibid., I 44-I45 (§XII.6) (footnotes omitted). Notice that Bentham discusses mental harms as harms worthy of consideration long before the law has recognised them as such.

${ }^{142}$ Ibid., 246-247 (§XVI.46) (footnote omitted). Bentham goes on to examine these ideas in more detail in ibid., 28I-293. 
There are times that even the words Beever quotes do not support his reading and provide no support for the forgetting thesis. Consider the following passage from Mill, which I quote here exactly as it appears in Beever's book:

It is no objection against this doctrine to say, that when we feel our sentiment of justice outraged, we are not thinking of society at large, or of any collective interest, but only of the individual case. It is common enough certainly, though, the reverse of commendable, to feel resentment merely because we have suffered pain; but a person whose resentment is really a moral feeling, that is, who considers whether an act is blamable before he allows himself to resent it-such a person, though he may not say expressly to himself that he is standing up for the interest of society, certainly does feel that he is asserting a rule which is for the benefit of others as well as for his own. If he is not feeling this-if he is regarding the act solely as it affects him individually-he is not consciously just; he is not concerning himself about the justice of his actions. ${ }^{143}$

Beever takes this to be an 'assert[ion] that it is axiomatic that all morality is reducible to distributive justice and that moral feelings must have distributive justice as their object' (232). But the quoted words, as is plain, say nothing of the sort. What they say is that while moral feelings (the 'sentiment of justice') may be personal, moral judgment must not be based on one's particular injury, unless this injury can be shown to be a wrong under a general, universal rule. A person who does not (implicitly) consider whether the particular event that befell him from the universal perspective of a general rule (that benefits others), is not a just person according to Mill. The content of Mill's justification of moral rules is utilitarian, but in its form Mill is expressing here the familiar idea of universalizability of moral judgments. In the history of philosophy this idea is associated mostly with Kant, Beever's foremost traditionalist.

That this is what Mill meant here was obvious to me upon reading the words quoted above as they appeared in Beever's book. To make sure, I went back to Mill's text and had my reading confirmed. Just a few words after the ones just quoted, in the same paragraph, Mill mentions Kant by name and quotes one of his formulations of the categorical imperative. Somehow, Beever managed to miss this unambiguous reference to what Mill was really talking about in pursuit of 'proving' his point. But if these words show that 'all morality is reducible to distributive justice' or that all 'moral feelings must have distributive justice as their object', then the same must be true of Kant.

It is plain, then, that this discussion has nothing to do with the question of Mill's views on the relationship between justice and interpersonal relationships. Does Mill say anything about this? Interestingly, only a few pages before the passage just quoted, in the same chapter, one finds Mill expressing ideas that will surprise anyone who learns their Mill by reading Beever: 'Justice implies something which it is not only right to do, and wrong not to do, but which some individual can claim from us as his

${ }^{143}$ John Stuart Mill, 'Utilitarianism', n I34 above, I87-I88, quoted in Beever's book at pp. 23 I232. 
moral right.' ${ }^{\prime 44}$ As Mill further explains, using terminology that will be entirely familiar from works of contemporary traditionalists, every case of injustice 'implies two things-a wrong done, and some assignable person who is wronged....It seems to

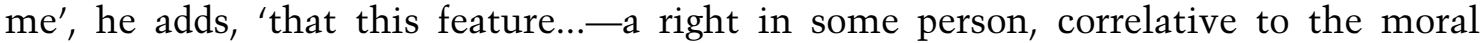
obligation-constitutes the specific difference between justice, and generosity or beneficence'. ${ }^{145}$ Can all this be reconciled with commitment to utilitarianism? Perhaps, perhaps not. What is not in doubt is that any fair representation of Mill's ideas would have to mention them and try to explain how someone who lived at a time when no-one could conceive of interpersonal relationships and who supposedly reduced all morality to distributive justice, could say them.

In the case of Sidgwick, Beever's distortion is twofold. Beever only mentions one of Sidgwick's books, The Methods of Ethics. What he does not do, however, is tell his readers that in that book there is an entire chapter entitled 'The Relation of Ethics to Politics'. In that chapter Sidgwick writes: 'Ethics aims at determining what ought to be done by individuals, while Politics aims at determining what the government of a state political society ought to do and how it ought to be constituted'. ${ }^{146}$ That is not a statement one would expect to find in a writer who conceives of all relations between individuals as deriving from the state. In that book there is also a chapter simply entitled 'Justice', in which Sidgwick, in trying to clarify the meaning of the term, seeks help by 'examin[ing] the notion of Justice as applied to that part of private conduct which lies beyond the sphere of law'. ${ }^{147}$ Sidgwick's answer is that justice in this context means being 'impartial..., seek[ing] with equal care to satisfy all claims which [one] recognises as valid and...not let[ting] [one]self be unduly influenced by personal preferences'. ${ }^{148}$ This answer may not be completely to Beever's liking, but it does contain some ideas found in the work of 'traditional' (e.g., justice as a mean), as well as 'modern' ones (the closest tie is to Hobbes's notion of impartiality). In any event, such passages show that Sidgwick was not indifferent to interpersonal relationships that exist outside the law and show that he held a much more nuanced view than Beever ascribes to him.

A more serious problem is that Beever fails to mention the book in which Sidgwick discusses private law, The Elements of Politics. ${ }^{149}$ It would take far too long, even for this Appendix, to discuss this book in any detail. Suffice it to say that that it contains chapters with titles like 'On Property', 'Contract', 'Inheritance', and 'Remedies for Wrongs'. The latter considers in some detail the distinction between civil (private) law and criminal law. Sigdwick is clear (and correct) in recognizing that

\footnotetext{
${ }^{144}$ Ibid., 185 .

145 Ibid.

${ }^{146}$ H. Sidgwick, The Methods of Ethics (London: Macmillan, 7th ed., I907) I 5.

147 Ibid., 268.

148 Ibid.

149 Sidgwick, n I33 above.
} 
civil law involves governmental intervention just as much as criminal law, but divides the line between the two in a manner reminiscent of contemporary law-and-economics writings:

where it is an adequate means of preventing wrongs to fix the burden of reparation on the wrongdoer, there is obviously no absolute necessity for any intervention of government: the required reparation may as well be made privately between the parties, so that it may properly be left to the option of the individual wronged to invoke the aid of government if necessary. On the other hand, where punishment-as distinct from reparation-is needed in the interest of the community at large, it must be the business of government to secure that it shall be inflicted whenever it is deserved to secure, therefore, that persons harmed by the crime shall come forward and give evidence, and shall not make peace with the criminal. And to attain this result, it is found more and more necessary, as civilisation advances, that government should make the prosecution of crimes its own business. ${ }^{150}$

This view gives place for interpersonal relations to do their job and brings in the law only when they are deemed insufficient.

\section{Conclusion}

I could go on and offer more examples, but to anyone who has made it to here, the point should by now be clear. As I pointed out in the conclusion of the main text of the essay, Beever's approach is extreme and idiosyncratic. This Appendix confirms this: not one of the philosophers Beever mobilizes for his cause actually supports anything resembling Beever's own view. Aristotle, Cicero (who receives a short chapter in Beever's book but whose views I did not discuss in detail here), Aquinas, and Pufendorf-all of them justify private property by appeal to its social benefits. Pufendorf and even Kant explicitly say that a social contract and political authority is necessary for the establishment of private property. The picture is distorted also in the other direction: Many modern theorists have no trouble recognizing, and even incorporating into their theory, interpersonal obligations that exist outside the state.

Ironically, the only one who comes close to Beever's view is John Locke (who Beever classified among the moderns), but Beever himself assessed his arguments and found them wanting. This does not mean that no argument for the traditional view can be made, but if Locke's arguments do not work, and as Beever himself admits that he does not offer a 'rigorous proof' (8) of his view, we are left at the end of the book with no real argument in defence of the traditional view. In the end, Beever's position remains based on his appeal to the reactions of small children (6), but it is doubtful even they could aid his case. True, children do develop notions of mine and thine at an early age, and they do so without a theory of distributive justice, but that it is doubtful that they do so on the basis of a theory of commutative justice either. For Beever to say that when something is taken from them it is 'the sense of injustice burning on a toddler's face' (2) is nothing but unverified (and possibly unverifiable) rhetorical fancy,

${ }^{150}$ Ibid., I I9. 
and especially so since toddlers often cry and protest when something is taken from them even when it is not actually theirs, which suggests that even if their crying is based on a 'sense of injustice', this sense is not very reliable.

In the end, if nothing else, there is no argument that overcomes what Beever calls 'the unilateral act problem' (I62) (the problem of generating rights good against the whole world on purely commutative grounds). This implies that Forgotten Iustice fails at what must be its reason for being: showing that there are two distinct forms of justice and that all of private law belongs to one of them. 